\title{
Prvi svjetski rat u kulturi sjećanja: inozemne i srpske ratne drame na repertoaru hrvatskih kazališta 1919. - 1941.*
}

\author{
MISLAV GABELICA \\ Institut društvenih znanosti Ivo Pilar \\ Zagreb, Hrvatska \\ Mislav.Gabelica@pilar.hr
}

\begin{abstract}
Polazeći od pretpostavke da se hrvatska kazališta između dva svjetska rata u kreiranju dramskoga repertoara nisu vodila samo umjetničkim nego i političkim obzirima, autor $\mathrm{u}$ članku analizira inozemne i srpske drame s temom Prvoga svjetskog rata koje su se u međuraću izvodile u tri hrvatska kazališta (u Zagrebu, Osijeku i Splitu) da bi odgovorio na pitanja kako je taj rat u tom razdoblju predstavljan hrvatskoj javnosti te kako je hrvatska javnost posredovanjem kazališne kritike reagirala na takvo njegovo predstavljanje.
\end{abstract}

Ključne riječi: Prvi svjetski rat; kazalište; ratna drama; hrvatska javnost

\section{Uvod}

Svrha je ovoga rada istražiti doprinos inozemnih i srpskih ratnih drama izvedenih u trima hrvatskim kazalištima (u Zagrebu, Osijeku i Splitu) između dva svjetska rata u formiranju kolektivnoga hrvatskog sjećanja na Prvi svjetski rat. U novije vrijeme fenomen kolektivnoga sjećanja proučavan je unutar koncepta kulture sjećanja, koji polazi od toga da svaka zajednica, pa tako i (hrvatska) nacionalna zajednica, preko mjesta sjećanja kao mjesta komemorativne prakse svjesno njeguje (kultivira) uspomenu na svoju prošlost da bi samu sebe u određenom trenutku legitimirala. ${ }^{1} \mathrm{U}$ ovom ću radu spomenutim hrvatskim kazalištima pristupiti kao mjestima sjećanja, a inozemnim i srpskim ratnim dramama izvedenima u njima u vrijeme prve jugoslavenske države kao sadržaju hrvatske kulture sjećanja na Prvi svjetski rat. Pristup kazalištu kao mjestu sjećanja smatram opravdanim jer je, za razliku od proznoga knji-

\footnotetext{
* Ovaj rad financirala je Hrvatska zaklada za znanost projektom IP-2019-04-5897 „Prvi svjetski rat u kulturi sjećanja. Zaboravljena baština”.

1 Vidi: ASSMANN, „Kultura sjećanja”, 45-78; HAMERŠAK, „Nacrt za pristup kulturnoj povijesti”, 12-14; MANOJLOVIĆ PINTAR, Arheologija sećanja, 34-35.
} 
ževnog teksta, koji je namijenjen intimnom čitanju, dramski tekst namijenjen javnom izvođenju te je zbog toga njegova sudbina ovisnija o utjecaju politike. Kazališni repertoar ne ovisi samo o umjetničkim ili tržišnim kriterijima (ukusu publike) nego i o kolopletu nadređenih politika, koje kazališnom politikom štite ili promiču svoje interese. Zato dramu ne možemo gledati samo kao izraz autorova intimnoga doživljaja svijeta, nego njezino postavljanje na kazališni repertoar moramo promatrati i kao politički čin, ovisan o utjecaju i željama neke zajednice.

Nehrvatske, inozemne i srpske ratne drame u prvom su redu izabrane jer se u hrvatskoj historiografiji o njima u ovom kontekstu dosad nije pisalo. S druge strane, o hrvatskim ratnim dramama je pisano. Povjesničar dramske književnosti Branko Hećimović unutar svojega iscrpnog rada o hrvatskoj dramskoj književnosti u međuratnom razdoblju ${ }^{2}$ spomenuo je i drame u kojima su se osjećali odjeci Prvoga svjetskog rata te ih je dijelio na one u kojima se svjetski rat tematizira usputno, bilo u sklopu drama nastalih u prvim poslijeratnim godinama koje karakterizira zanos jugoslavenskim nacionalno-političkim ujedinjenjem, ${ }^{3}$ bilo u sklopu onih „s motivom povratka s bojišta ili iz zarobljeništva”; ${ }^{4}$ zatim na drame u kojima su autori „direktno progovorili o ratnim danima" ${ }^{5}$ te na drame nastale uoči Drugoga svjetskog rata, koje s „pacifističkom tendencijom” govore o „Prvom svjetskom ratu, njegovim grozotama i tragikomičnim deformacijama ljudi”. ${ }^{6}$ Zbog relativno maloga broja hrvatskih drama koje su kao glavnu temu imale Prvi svjetski rat, kao i zbog maloga broja problema koje su otvarale, Hećimović je zaključio da je u hrvatskom dramskom stvaralaštvu u međuraću „velika tema rata ostala samo djelomično zahvaćena”.?

Hećimovićev zaključak podudara se s općenitim hrvatskim kolektivnim odnosom prema Prvom svjetskom ratu. Iako je sjećanje na taj rat vrlo brzo po njegovu svršetku zauzelo povlašteni status u javnom prostoru i kolektivnom pamćenju većine njegovih sudionika, pa je između dva svjetska rata među

\footnotetext{
2 HEĆIMOVIĆ, „Hrvatska dramska književnost”, 111-319.

3 Isto, 141-149. Od ovdje navedenih djela, motiv Prvoga svjetskog rata javlja se u izvedenim dramama Slijepci Danka Anđelinovića i Kuga Nike Bartulovića te u neizvedenoj drami Oluja Zofke Kveder-Demetrović.

4 Isto, 151-152. To su drame izvedene još tijekom rata: Mrak Pecije Petrovića (praizvedena u Zagrebu 9. prosinca 1916.) i Inoča Joze Ivakića (praizvedena u Zagrebu 1. rujna 1918.), zatim neizvedena drama Rudolfa Habeduša Ruine, napisana još 1917., te drama Bez trećega Milana Begovića (praizvedena u Somboru 11. rujna 1931.).

Isto, 151, 171-180, 255-256. To su Krležine drame Galicija (U logoru) i Vučjak, u kojima je Krleža „smjelo i znalački, otvoreno i kritički progovorio o tek proteklim ratnim danima na bojištima Galicije kao i o pozadinskoj atmosferi u jednoj novinskoj redakciji i seoskoj zabiti”, te Feldmanova drama Zec iz 1932., u kojoj se „prvi put nakon Krležine Galicije u hrvatskoj dramskoj književnosti progovara o prvom svjetskom ratu ali istodobno i o krvavoj zbilji austrougarskog militarizma".

${ }^{6}$ Isto, 266-280. To su drame Mali ljudi godine 1918. Ante Deana, U pozadini Miroslava Feldmana te Povratak Zlate Kolarić-Kišur.

7 Isto, 151.
} 
većinom pobjedničkih naroda bio njegovan kao kultura pobjede, a među većinom poraženih naroda (i Talijana) kao kultura poraza, ${ }^{8}$ u međuratnoj Hrvatskoj on nije stekao taj status, nego se prema tvrdnji suvremenika tamo primjećivala „općenita poslijeratna nezainteresiranost za zbivanja 1914-1918”. ${ }^{9}$ Tomu je bilo više razloga. U prvom redu velika većina Hrvata, oni koji su se borili na poraženoj strani i njihovi bližnji, nije mogla participirati u srpskoj kulturi pobjede jer je to bilo u suprotnosti s njihovim povijesnim naslijeđem, a prihvatiti tuđe naslijeđe značilo bi gubitak vlastitoga identiteta. Tek je mali dio Hrvata, oni koji su se borili u srpskim dobrovoljačkim postrojbama, participirao u toj kulturi, izgrađujući vlastitu kulturu sjećanja, u kojoj je mitsko mjesto (mjesto sjećanja) zauzimalo bojište u Dobrudži. ${ }^{10}$ Nasuprot tom sjećanju, koje su institucije jugoslavenske države snažno podupirale, među dijelom Hrvata čuvalo se sjećanje na prisilnu mobilizaciju u srpske dobrovoljačke postrojbe, pri čemu je središnje mjesto toga sjećanja bila Odesa, gdje su u ruskim zarobljeničkim logorima mučeni i ubijani oni Hrvati koji se nisu htjeli pridružiti srpskim dobrovoljačkim postrojbama. ${ }^{11}$

S druge strane, za razliku od onih poraženih naroda (i Talijana) koji su imali svoje države te su nakon rata osjećaj gubitka i poniženja „komemorativnim praksama" kanalizirali prema totalitarnim ideologijama i militantnim, revanšističkim poredcima, ${ }^{12}$ Hrvati nakon rata nisu stekli svoju državu, pa tako ni mehanizme za stvaranje takve kulture poraza. Umjesto toga, prema Johnu Paulu Newmanu, Stjepan Radić je kao vođa najjače hrvatske političke stranke u međuratnom razdoblju „u odsustvu pobede transformisao žrtvu hrvatskog vojnika u pacifističku, antimilitarističku poruku, koja je bila u dubokom sukobu sa oslobođenjem i ujedinjenjem", ${ }^{13}$ odnosno sa srpskom kulturom pobjede. Kako su pacifizam i antimilitarizam pojmovi suprotni ratnom nasilju i militarističkom duhu, takvo bi Radićevo djelovanje prije bilo njegovanje zaborava, a ne sjećanja na Prvi svjetski rat. Drugim riječima, Radić je hrvatsku kulturu poraza transformirao u kulturu zaborava Prvoga svjetskog rata.

\footnotetext{
8 NJUMEN, Jugoslavija u senci rata, 18-27.

9 HAMERŠAK, Tamna strana Marsa, 650-651, 658.

10 NJUMEN, Jugoslavija u senci rata, 214, 228-234.

11 Sjećanje na događaje u Odesi počelo se njegovati još za vrijeme rata, u ljeto 1918., kada je zastupnik „frankovačke” Stranke prava Aleksander Horvat o tome podnio interpelaciju u hrvatskom Saboru. Vidi: MATKOVIĆ, „Ratni zločini nad Hrvatima u Odesi 1916. (I)”, 34-38; MATKOVIĆ, „Ratni zločini nad Hrvatima u Odesi 1916. (II)”, 36-42; MATKOVIĆ, „Ratni zločini nad Hrvatima u Odesi 1916. (III)", 35-39. Poslije je simboliku Odese prihvatio i dio Hrvata jugoslavenske političke orijentacije. Tako je Miroslav Krleža, koji je inače pisao o Horvatovoj interpelaciji kao o „agitpropovskom” uratku i „posljednjem pokušaju frankovaca da zauzmu vlast u Hrvatskoj političkim prepadom", kritizirajući brutalnost jugoslavenskoga režima napisao: „U Odesi je počelo. U krvavoj Odesi, u 'Kanatnom zavodu', gdje se masakriralo en masse i gdje su pokapajući mrtvace rekli onom grobaru, da ne treba da znade tko su ti ljudi, 'jer su to Hrvati'. U Odesi se je klalo, tamo su pucale kosti i tamo su se davili utopljenici, i samo 23. oktobra 1916 ustrijeljeno je trinaest Hrvata poslije bune na Kulikovu polju." KRLEŽA, Deset krvavih godina, 282, 543-544.

12 MANOJLOVIĆ PINTAR, Arheologija sećanja, 36-37.

13 NJUMEN, Jugoslavija u senci rata, 164.
} 
Osim toga u Hrvatskoj se u međuraću sam Prvi svjetski rat našao u sjeni stvaranja jugoslavenske države, čiji su unutrašnji nacionalno-politički odnosi, unutar kojih je protekli rat bio tek jedna od komponenti, teško opterećivali politički život nove države. Zbog toga se organizirana komemorativna praksa hrvatske oporbe u međuratnom razdoblju, i one koja je težila neovisnoj hrvatskoj državi i one koja je težila povoljnijem položaju Hrvatske unutar jugoslavenskoga državnog okvira, nije odnosila na događaje i žrtve Prvoga svjetskog rata, nego na događaje i žrtve koji su simbolizirali otpor (centraliziranoj) jugoslavenskoj državi. ${ }^{14}$

U tom raskoraku između nametanja srpske kulture pobjede i „neiživljene” hrvatske kulture poraza, one koja bi težila uzvratu, formirana je specifična hrvatska kultura sjećanja na Prvi svjetski rat. Filip Hameršak prepoznao je na temelju proučavanja hrvatske književne i historiografske baštine najmanje dva hrvatska „mita” o Prvom svjetskom ratu koja su nastala u međuraću, a zadržala su se do današnjih dana. Prvi od njih je dominantniji te je od samoga stvaranja jugoslavenske države bio politički usmjeravan. Prema tome „mitu”, Austro-Ugarska Monarhija bila je tamnica hrvatskoga naroda i Hrvati su se u tom ratu (za nju) borili protiv svoje volje. Suština toga mita predočena je u Krležinu ratnom ciklusu, nastalom u međuratnom razdoblju, gdje se kao simbol hrvatskoga sudjelovanja u Prvom svjetskom ratu javlja kolektivni (anti)junak: neratoborni, nepismeni i prisilno mobilizirani zagorski domobran u dalekoj i blatnoj Galiciji. Nasuprot tome „mitu”, prema Hameršaku, javio se i inferiorniji „mit”, onaj o hrvatskom ratnom junaštvu u Prvom svjetskom ratu, koji je bio „slabije institucionalno podupiran”, zbog čega sve do danas nije uspio razviti čvrstu simboliku svojega narativa. ${ }^{15}$

Prvi od tih „mitova” u mnogočemu se podudara s tezom o transformaciji hrvatske kulture poraza u kulturu zaborava Prvoga svjetskog rata, pa je i Krleža, poput Radića, u svojim djelima promicao pacifistička i antimilitaristička stajališta, zbog čega je, opet poput Radića, dolazio u sukob sa srpskom kulturom pobjede. ${ }^{16}$ Postavlja se pitanje kako bi režim monarhističke Jugoslavije mogao podupirati prvi od "mitova” ako se taj isti „mit” sukobljavao sa srpskom kulturom pobjede, na kojoj je bila sazdana jugoslavenska država. Rješenje je u tome što se ni Radić ni Krleža nisu zaustavljali na sudjelovanju Hrvata u Prvom svjetskom ratu, nego su kao sljedbenici hrvatske tradicije ilirizma i jugoslavenstva, čije su se široke koncepcije uvijek iznova razbijale

14 Primjerice, komemoriranje žrtava vojne demonstracije na Jelačićevu trgu protiv stvaranja jugoslavenske države (5. prosinca 1918.); komemoriranje žrtava atentata u beogradskoj skupštini (20. lipnja 1928.); komemoriranje žrtava demonstracija koje su izbile u Zagrebu kao reakcija na taj atentat (21. lipnja 1928.); komemoriranje žrtava demonstracija koje su izbile prilikom obilježavanja desetogodišnjice stvaranja jugoslavenske države (1. prosinca 1928.). O tome vidi: GABELICA, MATKOVIĆ, Petoprosinačka pobuna u Zagrebu, 48-58; JAREB, Ustaško-domobranski pokret, 60-62.

15 HAMERŠAK, „Nacrt za pristup kulturnoj povijesti”, 21-29.

16 LASIĆ, Mladi Krleža i njegovi kritičari, 483-484, 493. 
o hridi srpskoga (i slovenskoga) nacionalizma, ${ }^{17}$ svojom kulturom zaborava htjeli obuhvatiti i srpsku kulturu pobjede. Drugi „mit”, onaj o hrvatskom ratnom junaštvu, u međuraću je bio blijedi odraz nepatvorene hrvatske kulture poraza, one koja je čekala drugu priliku i koja bez institucionalne podrške do danas nije uspjela postati sadržaj hrvatske kulture sjećanja na Prvi svjetski rat.

U tom kontekstu ovaj članak pokušat će odgovoriti na pitanje koliko su se nehrvatske (inozemne i srpske) ratne drame koje su se u međuraću našle na repertoaru hrvatskih kazališta svojim sadržajem, učestalošću izvođenja i reakcijom javnosti (preko kazališne kritike) podudarale s navedenim hrvatskim odnosom prema Prvom svjetskom ratu.

\section{Inozemne ratne drame na repertoaru hrvatskih kazališta}

Tijekom državnopravnoga provizorija, koji je trajao od prosinca 1918. do lipnja 1921., Narodno kazalište Kraljevstva Srba, Hrvata i Slovenaca u Zagrebu (poslije Narodno kazalište u Zagrebu) nalazilo se pod upravom Povjereništva za prosvjetu i vjere hrvatsko-slavonske pokrajinske vlade, podređene središnjoj vladi u Beogradu, te je od listopada 1919. uz kazališta u Beogradu i Ljubljani imalo status središnjega državnoga kazališta. Pod istom se upravom 1920. našlo i dotad privatno Hrvatsko narodno kazalište u Osijeku (poslije Narodno kazalište u Osijeku), koje je tom prilikom kao državno kazalište dobilo status oblasne institucije. Nakon donošenja Vidovdanskoga ustava, u lipnju 1921., hrvatsko-slavonska pokrajinska vlada počela je svoje ovlasti prepuštati središnjim državnim institucijama te je u idućem razdoblju upravu nad oba hrvatska kazališta neposredno preuzelo Ministarstvo prosvjete u Beogradu. Kako je tijekom provizorija pokrajinska vlada za Dalmaciju imala mnogo manje ovlasti od hrvatsko-slavonske pokrajinske vlade, tako se i 1920. osnovano Narodno pozorište za Dalmaciju u Splitu, kao oblasno kazalište, od samoga početka nalazilo pod izravnom upravom Ministarstva prosvjete u Beogradu. Kazalište u Zagrebu tijekom čitavoga međuraća sačuvalo je institucionalnu neovisnost, a kazališta u Osijeku i Splitu sjedinjena su 1928. odlukom Ministarstva prosvjete s drugim oblasnim kazalištima: prvo s novosadskim kazalištem u Novosadsko-osječko pozorište, a drugo sa sarajevskim u Narodno pozorište za zapadne oblasti. Novosadsko-osječko pozorište bilo je bez vlastite matične kuće te je čestim nastupima u Osijeku, kao i u drugim hrvatskim gradovima, djelomično sačuvalo i osječki, odnosno hrvatski identitet. S druge strane, matična kuća Narodnoga pozorišta za zapadne oblasti našla se u Sarajevu, pa je kazalište u Splitu od 1928. posve prestalo postojati. Bez vlastitoga kazališta, u Splitu je od 1931. do 1934. stalno nastupalo novosadsko-osječko kazalište pod nazivom Narodno kazalište za Primorsku banovinu. Nakon osnutka Narodnoga pozorišta Dunavske banovine u Novom Sadu, novosadsko-osječko kazalište dobilo je 1934. matičnu kuću u Osijeku, gdje je

17 O hrvatskom jugoslavenstvu vidi: LASIĆ, Mladi Krleža i njegovi kritičari, 315-322. 
od sljedeće kazališne sezone pa sve do uspostave Nezavisne Države Hrvatske djelovalo pod imenom Narodno kazalište kraljevića Tomislava. Uspostavom Banovine Hrvatske 1939. kazališta u Osijeku i Zagrebu, koje je ponijelo naziv Hrvatsko narodno kazalište u Zagrebu, došla su pod upravu banske vlasti, pod čijom se upravom našlo i 1940. osnovano Hrvatsko narodno kazalište u Splitu. ${ }^{18}$

Zbog ovisnosti o državnoj (banskoj) vlasti kazališne su uprave u određivanju repertoara prvenstveno morale voditi računa o nevidljivim granicama koje je vlast postavljala. Mnogo izravnije režim se upletao u kazališnu politiku s pravom da zabrani (daljnje) izvođenje predstava za koje je mislio da bi zbog hrvatskoga nacionalnog ili socijalnog sadržaja mogle biti opasne ili su se takvima pokazale nakon reakcija publike na njihovu izvedbu. Da bi se spriječilo da se i dalje troši vrijeme i novac na uvježbavanje predstava koje su se nakon izvođenja pokazale nepoćudnima, u zagrebačko je kazalište 1931. uvedena preventivna cenzura, prema kojoj se prije uvježbavanja predstave komisiji za cenzuru davao tekst drame na ocjenu. Ako bi ta komisija, koja je djelovala sve do 1941., tekst ocijenila sumnjivim, zabranila bi ga potpuno ili precrtala sumnjive dijelove, pa bi predstava bila uvježbana i izvedena bez tih dijelova. Unatoč tomu, i nakon uvođenja preventivne cenzure zabranjivane su predstave koje su prošle preventivnu cenzuru, ali su uoči izvođenja ili nakon toga ocijenjene ili su se pokazale opasnima. ${ }^{19}$

Kada je riječ o nevidljivim granicama koje je postavljala državna vlast, Slavko Batušić primijetio je da u međuratnom razdoblju na repertoaru hrvatskih kazališta gotovo da i nije bilo suvremenih sovjetskih pisaca, odnosno da su se tek od 30-ih godina počele prikazivati neke „neopasne” sovjetske komedije. ${ }^{20}$ Međutim, već od početka 20 -ih pa sve do 30 -ih u zagrebačkom i osječkom kazalištu u niz su navrata gostovali Moskovski hudožestveni (akademski) teatar (MHT), lojalan sovjetskoj vlasti, i nekoliko njegovih emigrantskih frakcija (Kočalovljeva skupina MHT-a, praška skupina MHT-a, disidenti praške skupine MHT-a), koji su uz ruske i svjetske klasike izvodili i djela suvremenih sovjetskih pisaca. ${ }^{21}$ Tako su u veljači 1931. disidenti praške skupine

18 HEĆIMOVIĆ, Repertoar hrvatskih kazališta, 380, 394, 462-463; S. BATUŠIĆ, „Vlastitim snagama”, 128-133; SENKER, Hrestomatija novije hrvatske drame, 19; FLOD, „Osječko kazalište”, 94-113; BOGNER-ŠABAN, „Hrvatsko narodno kazalište u Osijeku”, 9-23; MUCIĆ, Prvih četrdeset godina, 237-283; ĐORĐEVIĆ, „Teatar u Splitu”, 196-202.

19 S. BATUŠIĆ, Hrvatska pozornica, 171-175.

20 Isto, 173.

21 VAGAPOVA, „Skupine glumaca Moskovskog hudožestvenog teatra”, 29-42; MARIJANOVIĆ, „Hudožestvenici u Osijeku”, 334-341; VAGAPOVA, „Hrvatsko kazalište 20. stoljeća", 334-341. Smatra se da Kočalovljeva skupina, koja je djelovala u emigraciji 1919. 1922., nije bila emigrantska skupina u pravom smislu jer je sovjetsku Rusiju napustila legalno, odlazeći na gostovanje u Ukrajinu, gdje je privremeno zapela zbog građanskoga rata. Nakon dogovora sa sovjetskim vlastima dio Kočalovljeve skupine vratio se 1922. u Rusiju, gdje se pridružio svojemu matičnom, službenom MHT-u, a drugi dio ostao je u emigraciji i djelovao kao praška skupina MHT-a. Praška je skupina, među ostalim, na hrvatskim pozornicama izvodila i djelo suvremenoga sovjetskog pisca Maksima Gorkog, socijalnu dramu Na dnu života. 
MHT-a u Zagrebu izveli dramatizaciju Bulgakovljeva ratnoga romana Bijela garda, koji tematizira građanski rat u Ukrajini od stvaranja neovisne Ukrajine u sklopu njemačkoga protektorata 1918. do ulaska boljševičkih postrojbi u Kijev 1919. godine. Kako je roman napisan bez autorova izričitoga ideološkog pozicioniranja uz bilo koju od suprotstavljenih strana u građanskom ratu, emigrantska mu je kritika zamjerala simpatije prema boljševicima, a boljševička glorifikaciju predrevolucionarne prošlosti i simpatije prema nekim pripadnicima „bijeloga tabora”. ${ }^{22}$ Zagrebačka kritika u izvedbi te drame, osim općenitih poteškoća $u$ prenošenju romana u dramski tekst, nije primijetila ništa sporno, ${ }^{23}$ a beogradski tisak dramu je ocijenio „tendencioznom kopijom” romana, prekrojenog „u cilju ruske emigrantske propagande”, odnosno „moralnog bodrenja belogardista”. ${ }^{24}$

Osim izostavljanja suvremenih sovjetskih autora, u tom je razdoblju zabilježeno i potiskivanje autora s njemačkoga govornog područja s repertoara hrvatskih kazališta. Tijekom hrvatske moderne pa sve do početka Prvoga svjetskog rata od stranih komada na repertoaru zagrebačkoga kazališta francuske drame bile su nešto brojnije od drama autora s njemačkoga govornog područja. ${ }^{25}$ Tijekom Prvoga svjetskog rata drame autora s njemačkoga govornog područja više su nego dvostruko nadmašile izvedbu drama francuskih autora. U tom su razdoblju i drame engleskih (i američkih) autora dostigle, pa i prestigle izvedbu drama francuskih autora. ${ }^{26} \mathrm{U}$ međuraću su ponovo od stranih komada bile najbrojnije francuske drame, s time da su prvi put drame autora s engleskoga govornog područja nadmašile izvedbu drama autora s njemačkoga govornog područja. Na takav trend svakako je utjecala i „politička situacija", ${ }^{27}$ odnosno novo pozicioniranje Hrvatske unutar jugoslavenskoga okvira, što je za sobom vuklo i obračun s „dugotrajnim utjecajem kulturne paradigme njemačko-austrijske provenijencije u hrvatskom kazalištu” ${ }^{28}$

U nijansiranom pregledu toga trenda primijećeno je da su u prvih nekoliko poslijeratnih sezona njemačke drame potpuno nestale s repertoara zagrebačkoga kazališta, a prva se pojavila tek u sezoni 1922./23. Od tada pa sve do sezone 1928./29. njihov broj raste i te je sezone u zagrebačkom kazalištu odigrano šest njemačkih drama. U tom periodu česta su i vrlo dobro prihvaćena

\footnotetext{
22 PERUŠKO, „Rat i mir 20. stoljeća”, 13-14.

23 „Narodno kazalište”, Obzor (Zagreb), 27. 2. 1931., 2; „Bijela garda”, Jutarnji list (Zagreb), 28. 2. 1931., 8 .

24 „Pozorišni pregled”, Srpski književni glasnik (Beograd), 1931., knj. 32, br. 1, 63-67.

25 KOŠUTIĆ-BROZOVIĆ, „Francuske književne pobude”, 602.

26 GABELICA, „Dramski repertoar Kraljevskoga zemaljskoga hrvatskog kazališta”, 114 130 .

KOŠUTIĆ-BROZOVIĆ, „Hrvatsko dramsko prevoditeljstvo”, 280.

28 CAR, Odrazi i sjene, 191-192. Sličan trend postojao je i u drugim zemljama koje su nekad pripadale Austro-Ugarskoj Monarhiji, pa je 1931. hrvatski književnik Božo Lovrić, od 1913. stalno nastanjen u Pragu, lamentirao o nazadovanju praškoga kazališta, koje su u međuratnom razdoblju preplavile jeftine engleske i američke komedije. Božo LOVRIĆ, „Anglosasi osvojiše Prag”, Riječ (Zagreb), 10. 1. 1931., 9-11.
} 
gostovanja njemačkih i austrijskih kazališnih grupa u Zagrebu, što se podudaralo sa sve većim osjećajem razočaranja Hrvata novom državom, odnosno s jačanjem federalističke (i stare „austrokroatističke”) struje u hrvatskom društvu, pa je njegova unitaristička struja te drame i pozitivne reakcije zagrebačke publike na njih prepoznala kao opasnost, tražeći ili njihovu zabranu ili još češće izvođenje francuskih i engleskih autora da bi se neutralizirao navodno poguban utjecaj njemačke kulture na Hrvate. Od uvođenja Šestosiječanjske diktature broj njemačkih drama u zagrebačkom kazalištu ponovo pada te se sve do raspada jugoslavenske države po sezoni izvodilo dvije do tri njemačke drame, što se nije promijenilo ni za vrijeme Banovine Hrvatske. ${ }^{29}$

U drugoj polovini 30-ih, vanjskopolitičkim zaokretom Kraljevine Jugoslavije prema osovini Rim-Berlin, dolazi do bitne promjene u inozemnom dramskom repertoaru zagrebačkoga kazališta. Do sredine 30-ih izvodilo se u prosjeku po pet francuskih drama po sezoni, u sezonama 1936./37. i 1937./38. izvedena je po jedna, a od iduće sezone pa sve do raspada jugoslavenske države nijedna. ${ }^{30}$ Novi duh postao je vidljiv i u politici komisije za cenzuru zagrebačkoga kazališta, koja je 1937. dopustila izvođenje drame Bijela bolest Karela Čapeka uz uvjet da se „kod režiranja suviše ne podvlači pacifističko-propagandistički momenat” te da se "kod izbora uniforma i načina pozdravljanja dizanjem ruku izbjegava svaka aluzija na stanovitu vojsku i stanovite državnike - Hitlera, Musolinija, pok. Pilsudskog i sl." ${ }^{31}$

Ipak, tijekom cijeloga međuraća ni u zagrebačkom ni u drugim hrvatskim kazalištima nije izvedena nijedna njemačka ratna drama. ${ }^{32} \mathrm{Od}$ inozemnih autora monopol na temu Prvoga svjetskog rata u hrvatskim kazalištima imali su britanski (američki), francuski i čehoslovački pisci. Pritom su u ocjeni rata postojale razlike između britanskih (američkih) i francuskih ratnih drama s jedne strane i čehoslovačkih s druge. Sve su britanske (američke) i francuske ratne drame izvedene $\mathrm{u}$ hrvatskim kazalištima u međuratnom razdoblju bile antiratne te dio svjetskoga vala pacifističke literature, koji je počeo krajem 20-ih godina objavljivanjem dvaju književnih djela: ratne autobiografije engleskoga knji-

29 CAR, Odrazi i sjene, 191-236, 271-274.

30 KOŠUTIĆ-BROZOVIĆ, „Hrvatsko dramsko prevoditeljstvo”, 276; I. BATUŠIĆ, „Francuski umjetnici na zagrebačkoj pozornici”, 56.

31 S. BATUŠIĆ, Hrvatska pozornica, 176.

32 Najbliže izvođenju na jednoj od hrvatskih pozornica našla se Bitka na Marni (Die Marneschlacht) njemačkoga književnika i simpatizera Nacionalsocijalističke njemačke radničke stranke Paula Josepha Cremersa, praizvedena u Mannheimu u siječnju 1933. godine. GADBERRY, „Introduction”, 6. Ta se drama, koja je tematizirala odnose u njemačkom vrhovnom zapovjedništvu koji su doveli do poraza u bitci na Marni, počela pripremati u zagrebačkom kazalištu te je njezina zagrebačka premijera najavljena za rujan 1933. godine. „Bitka na Marni”, Kazališni list (Zagreb), 1. 9. 1933., 13; „Bitka na Marni”, Kazališni list (Zagreb), 15. 9. 1933., 3-8. Međutim drama je uoči premijere, „nakon glavnog pokusa”, zabranjena na intervenciju francuskoga veleposlanstva kod jugoslavenske vlade u Beogradu, navodno „jer je Cremers bio njemački pisac". S. BATUŠIĆ, Hrvatska pozornica, 174. Batušić ovdje navodi da je zabrana „nakon glavnog pokusa” uslijedila 1935. godine. No drama je na zagrebačkoj pozornici uvježbavana i najavljena za izvedbu već 1933. godine. 
ževnika Roberta Gravesa Zbogom svemu tom (Goodbye to All That) ${ }^{33}$ te romana njemačkoga književnika Ericha Marije Remarquea Na zapadu ništa novo (Im Westen nichts Neues). ${ }^{34}$ Jedna od tih drama, Grob neznana junaka (Le tombeau sous l'Arc de triomphe) francuskoga književnika Paula Raynala, premijerno izvedena u zagrebačkom kazalištu u listopadu 1932., praizvedena je još 1924. u Parizu, kada je izazvala oštre proteste francuske javnosti zbog navodnoga nepoštovanja žrtve francuskih vojnika. ${ }^{35}$ Tada je ta drama bila ispred svojega vremena, a desetak godina poslije optužba sadržana u njoj, da je starija generacija izdala mlađu šaljući ju u svjetski rat, u Francuskoj je već bila uobičajena. ${ }^{36}$

Pojava vala pacifističke literature krajem 20-ih vremenski se podudarala s uspostavljanjem novoga europskog suglasja o pitanju krivnje za svjetski rat, prema kojemu Njemačka više nije smatrana jedinim krivcem, nego su krivnju podjednako snosile sve europske države. ${ }^{37} \mathrm{Te}$ su dvije pojave, pacifizam i revidirano stajalište o pitanju krivnje za svjetski rat u zemljama pobjednicama $\mathrm{u}$ ratu, istjecale iz istoga izvora: iz postupnoga zaborava toga rata. Annika Mombauer primjećuje da su u Britaniji neposredno nakon rata revizionisti bili u znatnoj manjini, „no, kada su bijes i želja za osvetom u britanskoj javnosti minuli, službeno stajalište o uzrocima rata počelo se mijenjati”. ${ }^{38}$ Jednom kada nestane neprijatelja, lako je rat smatrati besmislenim; pa makar se u dokazivanju besmislenosti rata prolilo more tinte, to je poticanje zaborava, a ne njegovanje sjećanja na rat. Nasuprot tomu, u Njemačkoj pitanje revizije krivnje za rat nije izviralo iz zaborava rata niti je bilo vezano uz pacifizam, nego je bilo vezano uz poništenje pravnoga temelja na kojem je počivao sustav njemačkih ratnih reparacija. ${ }^{39}$ Zbog svega toga na taj val pacifističke literature, koji je bio simptom zaborava, u zemljama pobjednicama reagirali su književnici, koji su dokazivali da protekli rat nije bio besmislen, nego da se u njemu rješavala sudbina naroda. ${ }^{40}$ Prema tim reakcijama, obje su strane u ratu znale za što se bore te su u nj stupile oduševljeno. ${ }^{41}$

Ta se reakcija pojavila i na kulturnoj sceni Srbije, gdje je primjerice eminentni srpski književnik Miloš Crnjanski 1934. javno odbacio pacifizam uz koji je do tada pristajao, ${ }^{42}$ smatrajući ga pogubnim za srpsku kulturu pobjede,

\footnotetext{
33 Ivo HERGEŠIĆ, „Engleski ratni romani. Sheriffovim tragom”, Obzor, 4. 9. 1930., 3.

34 Ivo HERGEŠIĆ, „Roland Dorgles ili o ratnoj literaturi”, Hrvatska revija (Zagreb), god. 3 (1930), br. 3, 181-184. O oba književna djela kao o prijelomnim kulturnim događajima u buđenju interesa za Prvi svjetski rat vidi u: NJUMEN, Jugoslavija u senci rata, 171.

35 SACHS, McCREADY, „Stages of Battle”, 45-46.

36 McCREADY, „French Theater”, 11.

37 MOMBAUER, Uzroci Prvog svjetskog rata, 103-146. O tome vidi i članak Milana ŠUF-

FLAYA, „Val ratne krivnje”, Hrvatska revija, god. 2 (1929), br. 1, 45-53.

38 MOMBAUER, Uzroci Prvog svjetskog rata, 121-122.

39 Isto, 66-67.

40 Ivo HERGEŠIĆ, „Engleski ratni romani. Sheriffovim tragom”, Obzor, 4. 9. 1930., 3.

${ }^{41}$ Ivo HERGEŠIĆ, „Roland Dorgles ili o ratnoj literaturi”, Hrvatska revija, god. 3 (1930), br. 3, 183-184.

${ }^{42}$ Miroslav KRLEŽA, „M. Crnjanski o ratu”, Danas (Beograd), god. 1 (1934), br. 4, 55-60; POPOVIĆ, Život Miloša Crnjanskog, 162-165.
} 
na kojoj je počivala jugoslavenska država. ${ }^{43}$ U Hrvatskoj je javna kritika pacifizma i pacifističke literature bila bljeđa. Uglavnom je dolazila s lijeve strane hrvatskoga političkog spektra i odnosila se na nedovoljno izražen pacifizam te literature, kojem je na putu do pune afirmacije stajalo bilo nacionalno bilo klasno naslijeđe njezinih autora. ${ }^{44} \mathrm{Bez}$ vidljive političke tendencije, kritiku pacifističke literature uputio je i hrvatski teatrolog i književni povjesničar Ivo Hergešić, koji je u poplavi pacifističke literature uglavnom vidio plitko književno pomodarstvo. ${ }^{45}$

Prva od tih drama u hrvatskim kazalištima bila je Na kraju puta (Journey's End) engleskoga književnika Roberta Cedrica Sherriffa, koju je u travnju 1930. u zagrebačkom kazalištu izvela engleska kazališna grupa The English Players. ${ }^{46}$ Dramu je potom u lipnju 1930. u zagrebačkom kazalištu izvelo beogradsko Narodno pozorište na gostovanju kojem je svrha bilo „kulturno zbližavanje i lagano nivelisanje između Zagreba i Beograda" ${ }^{47} \mathrm{Na}$ kraju je istu dramu u studenom 1930. izvelo i zagrebačko Narodno kazalište, koje ju je do siječnja 1931. izvelo devet puta. ${ }^{48}$ Istovremeno je u listopadu 1930. dramu na repertoar stavilo i novosadsko-osječko kazalište, koje ju je na raznim gostovanjima izvelo 15 puta, ${ }^{49}$ među ostalim i u Splitu u ožujku 1931. godine..$^{50}$

Tu je dramu, koja prikazuje duševne lomove grupe engleskih časnika suočenih sa smrću u rovu na francuskoj bojišnici, većina hrvatskih kritičara

43 LASIĆ, Mladi Krleža i njegovi kritičari, 483-484. Približavanjem Drugoga svjetskog rata ta je reakcija u Srbiji bila sve izrazitija. Primjerice, nakon što je početkom listopada 1938. Njemačka zauzela Sudete, beogradski kazališni kritičar Dušan Krnić podsjetio je na to da je još u ožujku iste godine pozdravio beogradsku izvedbu Čapekove Bijele bolesti „kao delo pacifizma”, no da se vrlo brzo taj pacifistički ideal „stropoštao u razočarenje”. Sada je smatrao da je potrebno "ponoviti onaj divni poklič Trubača sa Drine” (Hej trubaču s bujne Drine srpska ratna pjesma Stevana Kaćanskog, dugo vremena smatrala se „srpskom marseljezom”, op. a.) da bi se probudio srpski nacionalni zanos. U tom cilju preporučio je dramu nastalu po romanu Stevana Jakovljevića Srpska trilogija, koja je „legendaran primer” „kako smo umeli da se žrtvujemo svesno za otadžbinsku zajednicu”. KRNIĆ, „Jakovljevićeva Srpska trilogija na pozornici”.

44 Vidi primjerice: Đorđe JOVANOVIĆ, „Romani o ratu”, Savremeni pogledi (Slavonski Brod), god. 2 (1936), br. 4, 83-88.

45 PERIČIĆ, Posrednici engleske književnosti, 202-203.

46 Ta je kazališna grupa u Zagrebu gostovala još nekoliko puta, a pri njihovu trećem gostovanju, u travnju 1931., u Zagrebu je gostovala i berlinska Opera. To je izazvalo reakciju tajnika Društva prijatelja Velike Britanije u Jugoslaviji, srpskoga književnika s boravkom u Zagrebu Milana Ćurčina, koji je vršio pritisak na zagrebačku kazališnu upravu da „nipošto ne dopusti da oba gostovanja padnu u isto doba, jer je van svake sumnje, da će u Zagrebu, zasad još, njemačka opera privući mnogo više općinstva nego engleski glumci. I zar to onda ne izgleda”, zaključio je Ćurčin, „kao da se naročito podupire njemačka propaganda protiv engleske?”. Milan ĆURĆIN, „Društvo prijatelja Velike Britanije u Jugoslaviji. Gostovanje 'English Playersa' i uprava Narodnog kazališta”, Jutarnji list, 23. 4. 1931., 8.

47 „Gostovanje beogradskog Narodnog pozorišta”, Novosti (Zagreb), 14. 6. 1930., 7.

48 HEĆIMOVIĆ, Repertoar hrvatskih kazališta, 139.

49 „Repertoar Narodnog kazališta u Osijeku od 3. listopada 1907. do 30. lipnja 1957.”, u: JELČIĆ, Spomen-knjiga o pedesetoj godišnjici, 220.

${ }^{50}$ „Na kraju puta”, Kazališni list (Split), 6. 3. 1931., 1-3. 
popratila iznimno pozitivnim kritikama. Ivo Hergešić pisao je da je to djelo uspjelo spojiti „lojalno domoljublje” s odlučnim, ali ipak nenametljivim pacifizmom, koji prije svega izvire iz uvjerljivoga prikaza straha i očaja engleskih vojnika. ${ }^{51} \mathrm{Uz}$ pacifističku crtu, „bez ikakve želje za doktrinarnim tezama", patriotsku notu u tom djelu istaknuo je i književni povjesničar katoličke orijentacije Ljubomir Maraković, koji je kao jedan od upečatljivijih dijelova drame naglasio trenutak kada njezini protagonisti svjesno odlaze u smrt, „ali nikom ne pada na um, da radi toga kritikuje komandu", u čemu je Maraković prepoznao divljenja vrijedno "gentelmanstvo" Engleza. ${ }^{52}$ Ista patriotska nota smetala je književniku i publicistu komunističke orijentacije Milanu Durmanu kada je pisao da se za autora toga djela „ne može reći da je povukao konzekvencije iz svojih ratnih iskustava”. Ipak, nadao se da će ono kod mlađih naraštaja uspjeti razotkriti „tobožnju romantiku besciljnog ratnog klanja i ono primitivno u stvari lažno čuvstvo koje se naziva - hrabrost". ${ }^{53}$

Sljedeća se u listopadu 1932. na repertoaru zagrebačkoga kazališta našla spomenuta Raynalova drama Grob neznana junaka, koja je u Zagrebu do siječnja 1933. izvedena osam puta. ${ }^{54}$ Njezina radnja tematizira odnos ratnika na bojištu i njegova zaleđa, a odvija se tijekom kratkotrajnoga dopusta francuskoga vojnika koji kod kuće zatječe zaručnicu, čiji su se osjećaji prema njemu počeli hladiti, te svojega oca, koji je u sinovljeve zaručnice postao njegov suparnik. U hrvatskom je tisku i ta drama pozitivno prihvaćena te je u njoj uglavnom prepoznata pacifistička poruka. ${ }^{55}$ Tek je književnik i publicist jugoslavensko-unitarističke orijentacije Branko Mašić ideju te drame prepoznao u veličanju „Neznanog Junaka”, koji simbolizira „beskrajne gomile mrtvih sa svim njihovim patnjama, ljubavlju, tragedijama i slavom, a što sve je žrtvovano na oltar domovine, za spas i sreću budućih generacija”, pri čemu je dramu usporedio s Vojnovićevom Smrti majke Jugovića. ${ }^{56}$ Suprotno Mašiću, najjasnije se izrazio Ljubomir Maraković, koji je tragediju te drame prepoznao upravo u tome što u njoj žrtva „neznanog junaka” ne počiva na „patriotskoj eksaltaciji”, nego na besmislenosti njegove žrtve „i na nekoj, jedva čulnoj, latentnoj poruzi na račun te bezimene slave, koja je u biti posve drugačija nego što je zamišljaju ljudi u pozadini ili 'zahvalni potomci'”. ${ }^{57}$

Za razliku od Zagreba, gdje je pacifizam sadržan u toj drami, ako je prepoznat, bio neupitna vrijednost, u Beogradu, gdje je drama izvedena u veljači 1937., pacifizam se propitivao. Tako je srpski kritičar Konstantin Atanasijević

\footnotetext{
${ }^{51}$ Ivo HERGEŠIĆ, „Još o ratnoj literaturi”, Hrvatska revija, god. 3 (1930), br. 7, 409-410.

52 Ljubomir MARAKOVIĆ, „Gostovanja i premijere u Narodnom kazalištu”, Hrvatska straža (Zagreb), 8. 4. 1930., 4.

53 Milan DURMAN, „Sherriff: Svršetak puta”, Književnik (Zagreb), god. 3 (1930), br. 12, 574 .

54 HEĆIMOVIĆ, Repertoar hrvatskih kazališta, 142.

55 Josip HORVAT, „Grob neznanog junaka”, Jutarnji list, 15. 10. 1932., 5; Krešimir MLAČ, „Hrvatsko kazalište”, Luč (Zagreb), god. 28 (1932/33), br. 3-4, 108-109.

56 Branko MAŠIĆ, „Grob neznanog junaka”, Novosti, 10. 10. 1932., 5.

57 Ljubomir MARAKOVIĆ, „Dvije tragedije”, Hrvatska straža, 4. 11. 1932., 4.
} 
podsjetio na to da je svojevremeno ta drama u Parizu uzrokovala bučne sukobe između „pristalica rata” i pacifista te primijetio da je tekst drame prikazivane u Beogradu očišćen od većine ključnih proturatnih fraza. Time je, prema Atanasijeviću, ona izgubila svaku vrijednost te je spriječena uloga beogradskoga kazališta kao prostora poželjnoga sukoba suprotstavljenih stajališta o vrijednosti rata u srpskom društvu. ${ }^{58}$

Novosadsko-osječko kazalište izvelo je u studenom 1933. dramu američkoga književnika Roberta Emmeta Sherwooda Na londonskom mostu (Waterloo Bridge), koju je odigralo ukupno pet puta. ${ }^{59}$ Ista je drama u srpnju 1934. izvedena u Zagrebu, gdje je ponovljena još šest puta. ${ }^{60}$ Radnja se odvija tijekom rata u Londonu, odakle se kanadski dobrovoljac sprema uputiti na europsko ratište. Pred polazak na ratište na londonskome mostu upoznaje djevojku u koju se, ne znajući da je prostitutka, zaljubi. Kada mu ona otkrije što je, on ju prihvaća i želi se njome oženiti, no u sukobu između ljubavi i vojne dužnosti u njemu prevladava osjećaj dužnosti te on odlazi. Najpozitivnije je dramu ocijenio Josip Horvat, koji je u njoj vidio „najbolju predstavu ove sezone”, smatrajući da njezina snaga izvire iz „pacifističke tendencije ali bez velikih fraza i naglašenosti”. ${ }^{61}$ Najnegativnije ju je ocijenio književni časopis komunističke orijentacije Književnik, koji je uređivao Milan Durman, gdje je drama ocijenjena „prosječno sentimentalnim” djelom „na način novela u američkim magazinima”, nastalim na valu konjunkture ratne literature. ${ }^{62}$

Zatim je u lipnju 1934. u Zagrebu premijerno izvedena drama engleskoga književnika Williama Somerseta Maughama Za zasluge (For Services Rendered), koja prikazom propasti jedne engleske malograđanske obitelji tematizira poguban utjecaj rata na englesko poslijeratno društvo. Zagrebačko ju je kazalište do siječnja 1937. izvelo deset puta ${ }^{63}$ te je s njom u listopadu 1935. gostovalo i u Splitu. Sva je zagrebačka kritika dramu ocijenila uspjelom, ${ }^{64}$ osim novinara komunističke orijentacije Branimira Grškovića, koji ju je nazvao dosadnom i pacifistički tendencioznom, pri čemu je za motive na kojima je Maugham gradio tu svoju tendenciju (materijalna nesigurnost, alkoholizam) smatrao da nisu nužno posljedice rata, nego dubljih razloga: „Autor je sve samo načeo, zagrabio je samo po površini a nije pogledao dublje: zašto su svi ti ljudi ne-

58 ATANASIJEVIĆ, „Grob neznanog junaka od Pol Renala”.

59 HEĆIMOVIĆ, Repertoar hrvatskih kazališta, 501.

60 Isto, 145 .

${ }^{61}$ Josip HORVAT, „Na londonskom mostu”, Jutarnji list, 7. 7. 1934., 9.

62 „R. E. Sherwood: Na londonskom mostu”, Književnik, god. 7 (1934), br. 8, 379-380. U kontekstu kritike njezine površnosti o njoj je pisano: „Današnja internacionalna situacija u vidu svestranih priprema novih ratnih zapletaja zahtijevala bi doduše propagandu protiv imperijalističkog rata, no upravo takva situacija zahtijeva osnovni idejni stav i snagu argumentacije (uz izrazite literarne kvalitete), koju ne možemo ni tražiti od pisca toliko osrednjih kvaliteta kao što je Sherwood."

63 HEĆIMOVIĆ, Repertoar hrvatskih kazališta, 145.

64 „W. S. Maugham”, Književnik, god. 7 (1934), br. 7, 336-338; Branko MAŠIĆ, „Za zasluge”, Novosti, 9. 6. 1934., 6; Branimir LIVADIĆ, „Kazalište”, Hrvatska revija, god. 7 (1934), br. 7 , 380 . 
sretni. Nije išao do kraja, htio je zaroniti a samo je mlatarao po vodi." ${ }^{65}$ I u Splitu je jedan od čelnika dalmatinske Orjune, književnik Ćiro Čičin Šain, tu dramu ocijenio djelom „sa naglašenom tendencom pacifističke propagande” i zbog toga umjetnički manjkavim. ${ }^{66}$ Možemo pretpostaviti da je Šainov negativan odnos prema „pacifističkoj propagandi” u književnosti bio uzrokovan i strahom od urušavanja jugoslavenske države jer je dramu pacifistički tendencioznom ocijenio i književnik katoličke orijentacije Vojmil Rabadan, poznat po kazališnoj adaptaciji Budakova romana Ognjište ${ }^{67}$ no on je smatrao da ta tendencija „nije nimalo na uštrb umjetničkoj strani djela”. ${ }^{68}$

Manju pozornost hrvatske kritike izazvala je još jedna drama Paula Raynala, Marna (La Francerie), koja je od svibnja do lipnja 1936. u zagrebačkom kazalištu izvedena samo tri puta. Radnja se odvija 1914. na zaposjednutom području Francuske, u pozadini bitke na Marni, gdje tijekom bitke jedan njemački časnik u razgovoru s dvoje Francuza od trijumfalizma evoluira do pacifizma. Dramu je uspjelom ocijenio Branimir Livadić, premda je držao da „tendenciozno” razvija pacifističku ideju i da su pacifistički ideali sadržani $\mathrm{u}$ njoj samo plod svojega vremena, a ne trajna vrijednost. ${ }^{69}$ Branimir Gršković dramu je ocijenio „nepotrebnom”, jer je zagrebačka publika „sita rata”, te ismijao autorovo viđenje pacifizma u prikazu njemačkoga časnika, usto i pruskoga plemića, koji pri kraju predstave „drži pacifističke tirade nakon što je zveckao ostrugama i hrustio se pobjedom" ${ }^{70}$

65 Branimir GRŠKOVIĆ, „Sinoćnja premijera u velikom kazalištu”, Večer (Zagreb), 8. 6. 1934., 5. U Beogradu, gdje je drama izvedena u svibnju 1934., kritika iz komunističke perspektive bila je ideološki izraženija. Tamo je anonimni kritičar pisao da se u drami „vrši likvidacija buržoaske familije, jer je počivala na bazi novca i izvesnog morala ugleda, dakle na trošnoj osnovi, koju izraz egoizma, rat, smrvi pa i na njoj seje egoizam. Samo tu likvidaciju ne primećuje niko dovoljno, a najmanje sam pisac. On od svojih ličnosti pravi heroje mučenja, a u stvari to su heroji sa izgubljenim šansama i to sa buržoaskim šansama”. „Za zasluge. Drama u tri čina od Somerset Mona”.

66 Ćiro ČIČIN ŠAIN, „Pacifistička propaganda u kazalištu”, Novo doba (Split), 26. 10. 1935., 6 .

67 JONJIĆ, MATKOVIĆ, Iz korespondencije dr. Mile Budaka, 89.

68 Vojmil RABADAN, „W. S. Maugham: Za zasluge”, Jadranski dnevnik (Split), 26. 10. 1935., 3. Rabadanova ocjena to je zanimljivija što je Maugham bio nepoćudan katoličkim krugovima, među kojima je slovio za istaknutoga predstavnika engleskoga liberalizma, pa je navodno i vatikanski list L'Osservatore Romano početkom 30-ih godina „osudio Maughama i njegove nastrane ideje”. Osobito sporna bila je njegova drama Sveti plamen (The Sacred Flame), koju su tijekom 30-ih s velikim uspjehom izvodili zagrebačko i novosadsko-osječko kazalište. Drama se odvija nekoliko godina nakon Prvoga svjetskog rata i bavi se istragom ubojstva mladića, bivšega vojnika koji je u ratu ostao nepokretan. Istraga se odvija u krugu obitelji, a za ubojstvo je osumnjičena mladićeva supruga, koja je, zaljubivši se, zanijela s njegovim bratom. U završnici drame saznaje se da je mladića ubila vlastita majka, potaknuta milosrđem da jednoga sina liši razočaranja, a drugom omogući sretan život s voljenom ženom, što obitelj naposljetku prihvaća kao opravdan čin. Kritiku Maughama i ove njegove drame iz hrvatskih katoličkih krugova vidi u: Vilko RIEGER, „Sveti plamen”, Nedjelja (Zagreb), 21. 9. 1930., 376; Ljubomir MARAKOVIĆ, „Maughamov Sveti plamen”, Hrvatska straža, 18. 9. 1930., 4.

69 Branimir LIVADIĆ, „Paula Raynala Marna”, Hrvatska revija, god. 9 (1936), br. 7, 374.

70 Branimir GRŠKOVIĆ, „Kazališna kronika”, Večer, 28. 5. 1936., 6. 
Čehoslovačke ratne drame izvedene na hrvatskim pozornicama u ocjeni rata razlikovale su se od britanskih (američkih) i francuskih. Dok su Velika Britanija, Sjedinjene Američke Države i Francuska bile neupitno pobjedničke države, Čehoslovačka je stvorena tek krajem rata, a većina Čeha i Slovaka do kraja se rata lojalno borila na strani poražene Austro-Ugarske Monarhije. Međunarodno priznanje i status pobjedničke zemlje nakon rata Čehoslovačka je stekla političkim putem, poglavito zaslugom čehoslovačkih legija, dobrovoljačkih postrojbi sastavljenih od čeških i slovačkih ratnih zarobljenika koje su se tijekom rata borile na strani Antante te su se i nakon rata u Rusiji nastavile boriti protiv boljševika. ${ }^{71}$ Zbog toga si čehoslovački pisci, ako su htjeli legitimirati novi svjetski poredak zaslužan za stvaranje njihove države, nisu mogli dopustiti velikodušni pacifizam povezan s relativiziranjem krivnje za rat, nego su s jedne strane demonizirali Austro-Ugarsku Monarhiju, a s druge strane gradili kult svojih legionara. ${ }^{72}$

Najznamenitije čehoslovačko književno djelo u međuratnom razdoblju bio je satirični ratni roman Jaroslava Hašeka Doživljaji dobrog vojnika Švejka u svjetskom ratu (Osudy dobrého vojáka Švejka za světové války), koji se vrlo često tumači kao univerzalno proturatno djelo. Međutim, prema drugom tumačenju, temeljenom na Hašekovu dobrovoljnom stupanju u čehoslovačku legiju, gdje nije bio protivnik ni stroge hijerarhije ni discipline, ${ }^{73}$ ovaj je Hašekov roman u prvom redu protuaustrijsko djelo. ${ }^{74}$ Što se tiče književnih djela koja su obrađivala legionarsku temu, u međuraću se osobito isticao književnik František Langer, koji je kao nekadašnji pripadnik čehoslovačke legije napisao više djela na tu temu: drame Konjanička izvidnica (Jízdní hlídka) i Pobjednici (Vitězové) te dječji roman Pas druge čete (Pes druhé roty). ${ }^{75}$

U Zagrebu je dramatizacija Hašekova romana prvi put izvedena u rujnu 1928. te je do lipnja 1933. ta drama izvedena čak 74 puta, što je bio „broj kojim se nije moglo pohvaliti u tako kratkom razdoblju nijedno djelo ni domaćeg

71 RADA et al., Povijest Češke, 500, 525-526.

72 Predstavljajući pjesmu češkoga pjesnika Ladislava Narcisa Zverine Češka rapsodija, objavljenu 1919. povodom druge obljetnice čehoslovačke državnosti, Jugoslavenska njiva usporedila ju je s Krležinom Hrvatskom rapsodijom: „Češki rapsodist pjeva arma virumque čeških legionara, o češkoj 'mafiji', o svim herojima koji se borahu za ovaj svjetski prevrat, pjeva i o jugoslavenskom Principu i Čabrinoviću, a naš se 'rapsodist' naprotiv nazvao rapsodom od ironije, nema što da pjeva, nema herojstva u nas, pa pjeva s ironijom, s optužbom krvavu satiru o ropstvu našemu za vrijeme rata, o prostituciji našeg gradjanstva...” „Književnost i umjetnost", Jugoslavenska njiva (Zagreb), god. 3 (1919), br. 3, 47-48.

73 Hašek je potom dobrovoljno stupio i u službu ruske boljševičke vlasti, gdje je obnašao političke i vojne dužnosti. O tome vidi: Jaroslav MALI, „Hašekovi feljtoni o sovjetskoj Rusiji”, Srpski književni glasnik, 1937., knj. 52, br. 2, 139-141.

74 HAMERŠAK, „Nacrt za pristup kulturnoj povijesti”, 26, 50; HAMERŠAK, Tamna strana Marsa, 206. U međuratnom je razdoblju s jugoslavenskoga unitarističkog stanovišta doveden u pitanje načelni antimilitarizam Miroslava Krleže. LASIĆ, Mladi Krleža i njegovi kritičari, 474-475.

75 Ante NEIMAROVIĆ, „Ratna književnost”, Omladina (Zagreb), god. 16 (1934), br. 10, 153-154. 
ni stranog autora" ${ }^{76}$ Sličan uspjeh drama je imala i u Osijeku, gdje je prvi put izvedena u studenom 1928., a do lipnja 1931. novosadsko-osječko kazalište izvelo ju je 32 puta, od čega najmanje dva puta u Splitu. ${ }^{77}$ Ta se dramatizacija, koju su priredili Max Brod i Hans Reimann, „i više nego labavo” držala svojega književnog predloška ${ }^{78}$ te je Hašekova satirična oštrica u njoj uvelike bila otupljena, ${ }^{79}$ pri čemu je, čini se, više stradala univerzalna proturatna komponenta djela nego njegova protuaustrijska sastavnica. Većina hrvatskih kritičara dramu je ocijenila plitkom, nepretencioznom komedijom, ${ }^{80} \mathrm{~s}$ tim da je za Kalmana Mesarića ona bila tek „vicem” na račun austrougarske vojske, ${ }^{81}$ a za dramatičara Petra Preradovića, unuka austrijskoga časnika i pjesnika Petra Preradovića, i taj vic bio je više nego neukusan. ${ }^{82}$

Sličnu ocjenu doživjela je i jedna kasnije izvedena „Švejkova imitacija”. Riječ je o „lakrdiji iz života austro-ugarskih vojnika” Fajfka Petržel češkoga književnika Richarda Havelke, premijerno izvedenoj u osječkom kazalištu u listopadu 1936. godine. Iako je osječka premijera predstave bila „odlično” posjećena te je predstava do lipnja sljedeće godine izvedena još deset puta, ${ }^{83} \mathrm{hr}$ vatski nacionalistički list u Osijeku Hrvatski list ${ }^{84}$ smatrao je izvedbu te drame u Osijeku nepotrebnom: „Ako se radilo samo o 'idejnoj' strani djela, narugivanju austro-ugarskom militarizmu, tada čak niti to ne može biti opravdanje, jer u tako slabom okviru mora propasti i ta danas posve neaktualna tema” jer „sada, gdje smo već odavna likvidirali problem austro-ugarskog militarizma, upravo je deplasirano, gotovo neukusno, razmetati se tako zakašnjelim i neriskantnim junaštvom." ${ }^{\text {g }}$

U svibnju 1936. u Zagrebu je izvedena Langerova drama Konjanička izvidnica, koja je do lipnja iste godine izvedena četiri puta. ${ }^{86}$ Drama tematizira povlačenje grupe čeških legionara kao dijela Kolčakove vojske 1919. kroz Sibir da bi se preko Vladivostoka domogli domovine. Većina hrvatskih kritičara dramu je shvatila kao patriotsko djelo, pišući primjerice da se u njoj odražava

76 KOŠUTIĆ-BROZOVIĆ, „Hrvatsko dramsko prevoditeljstvo”, 276.

77 „Repertoar Narodnog Kazališta”, Novo doba, 9. 4. 1931., 5.

78 HAMERŠAK, „Od romana do izvedbe”, 129.

79 Isto, 132.

80 Isto, 133-140.

81 Isto, 135.

82 Isto, 136.

83 HEĆIMOVIĆ, Repertoar hrvatskih kazališta, 505.

${ }_{84}$ Prema Božidaru Novaku, od osnutka 1920. do 1926. Hrvatski list izlazi kao glasilo federalističke Hrvatske zajednice, a zatim podupire politiku Hrvatske seljačke stranke. Nakon uvođenja diktature 1929. list je „izmijenio pisanje i samo informira”. Početkom 30-ih list je „otišao u lijevo i pisao protiv centralističkog uređenja države, a traži i republikansku formu vladavine”. Krajem 30-ih list je „neodređen, ali separatistički”. NOVAK, Hrvatsko novinarstvo u 20. stoljeću, 129. Mario Jareb precizira da je taj list još sredinom 30-ih „slijedio politiku HSS-a”, a u drugoj polovini toga desetljeća počeo zastupati „proustaška” stajališta. JAREB, Ustaško-domobranski pokret, 545.

${ }_{85}$ Ernest DIRNBACH, „Fajfka Petržel”, Hrvatski list (Osijek), 3. 11. 1936., 11.

86 HEĆIMOVIĆ, Repertoar hrvatskih kazališta, 148. 
„sav heroizam tih jednostavnih i priprostih ljudi, svi oni nadčovječni napori i ogromne žrtve koje su legionari doprinijeli u cilju izgradnje svoje samostalne države" 87 ili da je ideja za koju se glavni akteri drame bore „sloboda vlastitog naroda”, koja je „jača od svih zamamljivih ponuda boljševičkih trupa pa oni rađe umiru nego da se iznevjere toj uzvišenoj ideji". ${ }^{88}$ Samo je kritičar Obzora Rudolf Maixner primijetio da je u vrijeme odvijanja te drame ideal za koji su se češki legionari borili, „njihova nezavisna država”, već bio ostvaren te da se glavni akteri drame „bore protiv boljševika za stvar koja im je tudja i samo zato što su 'oni', to jest veliki saveznici tako odlučili”. Kako im nedostaje „ideja za koju se bore”, „njihova je glavna težnja čisto animalna, da sačuvaju glavu i vrate se kući”. Ipak je i Maixner u toj drami prepoznao Františekov „patriotski čin” - pružiti „jedno čovječansko opravdanje sibirskoj akciji čehoslovačkih legionara, koja je u njegovoj domovini a i izvan nje bila predmet tolikih rasprava". ${ }^{89}$

Na kraju je u Osijeku u siječnju 1939. izvedena ratna komedija češkoga književnika Emila Vacheka $\mathrm{Na}$ peći $(\mathrm{Pec})$, koja je do svibnja iste godine ponovljena još pet puta..$^{90}$ Ista drama premijerno je izvedena u Zagrebu u veljači 1939., gdje je do ožujka te godine izvedena ukupno šest puta. ${ }^{11}$ Radnja se odvija 1916. u jednom selu u Ukrajini, gdje na imanju živi mlada, no lijena i zapuštena Marfa, čiji se muž već dvije godine nalazi u ruskoj vojsci. Kada je od ruskih vlasti kao ispomoć za rad na imanju dobila ratnoga zarobljenika, Čeha Vaclava Adameca, u koga se zaljubila, Marfa je procvjetala, dovela imanje u red te naučila čitati i pisati. ${ }^{92}$ Motiv nevjerne žene prisutan je i u velikom dijelu hrvatskih drama koje se kao glavnom ili sporednom temom bave povratkom iz rata, no dok su u tim dramama hrvatski ratnici (koji kao da nisu dostojni vjernosti svojih žena) ti koji su varani, u ovoj je češkoj drami Čeh taj zbog kojega Ukrajinka vara svojega muža i koji civilizira zapuštenu ženu. Taj izraz češkoga trijumfalizma prepoznao je književnik i književni kritičar hrvatske nacionalističke orijentacije Dušan Žanko, koji je pisao da je to djelo, koje počiva na „kulturträgerstvu” Čeha među navodno primitivnim Ukrajincima, „komediografski hir, koji je u Češkoj iz razumljivih razloga mogao draškati ponos kulturnoga centruma, koji je tobože iznad ukrajinske džungle u osnovnim pojmovima morala. Ali u hrvatskom kulturnom centrumu”, odnosno u Zagrebu, „nije trebalo prodavati rog za svijeću”. ${ }^{93}$

Kako se vidi iz dosadašnjega izlaganja, od inozemnih je ratnih drama $\mathrm{u}$ hrvatskim kazalištima u međuratnom razdoblju izvedeno pet britanskih (američkih) i francuskih drama s naglašenom pacifističkom tendencijom te

\footnotetext{
87 „Konjanička izvidnica F. Langera”, Komedija (Zagreb), 10. 5. 1936., 1.

88 „Kazalište. F. Langer: Konjanička izvidnica”, Narodne novine (Zagreb), 19. 5. 1936., 3.

${ }^{89}$ Rudolf MAIXNER, „F. Langer: Konjanička izvidnica”, Obzor, 22. 5. 1936., 2.

90 HEĆIMOVIĆ, Repertoar hrvatskih kazališta, 508.

${ }^{91}$ Isto, 152.

92 „Peć”, Komedija, 12. 2. 1939., 1-4.

93 Dušan ŽANKO, „Emil Vachek: Na peći”, Hrvatska smotra (Zagreb), god. 7 (1939), br. 4 , 218-219.
} 
četiri čehoslovačke drame, koje su karakterizirali protuaustrijska nota i češki nacionalizam. Prve su bile izvedene oko 60 puta, što je bilo znatno manje od broja izvedbi čehoslovačkih ratnih drama - oko 130 puta. Prvenstveni uzrok tomu bio je izniman uspjeh drame Doživljaji dobrog vojnika Švejka na hrvatskim pozornicama. Osim toga primjećuje se da su te drame doživljavale kritike iz različitih hrvatskih kulturno-političkih krugova. Britanske (američke) i francuske ratne drame najizrazitije su bile kritizirane iz ljevičarskih krugova, a čehoslovačke iz hrvatskih nacionalističkih krugova.

\section{Srpske ratne drame na repertoaru hrvatskih kazališta}

Vrlo brzo nakon rata i s hrvatske i sa srpske strane utvrđene su osnovne razlike između hrvatske i srpske ratne literature. Pritom je srpska strana utvrdila razlike između ratne literature nastale na tlu predratne Srbije i one nastale na bivšem području Austro-Ugarske Monarhije te je u ovu posljednju, uz Krležu, uvrstila i ugarskoga Srbina Miloša Crnjanskog, koji je u to vrijeme još bio protivnik rata. Prema viđenju srpske strane, „ratna i poratna pričanja” Krleže i Crnjanskog bila su plod njihova života u Austro-Ugarskoj Monarhiji, nemoralnoj i anacionalnoj tvorevini, gdje se nije borilo za pravedan, nacionalni cilj, pa je zbog toga rat u njihovu diskursu prljav, a sam je diskurs antimilitaristički i revolucionaran, buntovnički. S druge strane predratna je Srbija bila vitalan nacionalni organizam, pa je zbog toga u diskursu književnika s područja Srbije „taj rat zdrav i zna se zašto je”, a sam je taj diskurs tek „reformno militaristički”. Književnici s područja Srbije „snagom stvari” nisu buntovnici nego „reformisti”. „Njihov rat je rat sviju za jedan stvaralački cilj, od kojeg očekuju dobro, istinito i lepo. Oni se ne bune i ne nariču, jer smatraju da je taj rat prav i za pravo. [...] U koliko i ima protesta i bunta, oni su dobronamerni i stvaralački. [...] Nešto otrova ima, ali on nije ubistven." ${ }^{\prime 4}$ S hrvatske je strane konciznije navedeno da je „opredjeljenje stava hrvatskog naroda prema ratu” predstavljeno u Krležinu ratnom ciklusu, a da se među Srbima profilirala „epska glorifikacija rata s više ili manje ličnog kriticizma i pesimizma". ${ }^{5}$ Unutar toga diskursa kretala se i srpska ratna drama u međuratnom razdoblju. Borba Srbije u svjetskom ratu bila je neupitna vrijednost, a više ili manje loše i razočaravajuće bile su tek posljedice rata.

Prva srpska ratna drama izvedena u nekom od hrvatskih kazališta bio je Vrtlog hrvatskoga Srbina Vladimira Velmar-Jankovića. Drama je prvi put prigodno izvedena u Osijeku 29. listopada 1922., na četvrtu godišnjicu prekida državnopravnih veza Hrvatske s Ugarskom i Austrijom, ${ }^{96}$ te je do studenoga iste godine izvedena još dvaput. ${ }^{97}$ Rodom iz Čaglića kod Lipika, Janković se

94 Branko LAZAREVIĆ, „Predratna i poratna pričanja”, Srpski književni glasnik, 1922., knj. 5, br. 6, 431-442.

95 „Hrvatski bog Mars”, Obzor, 1. 1. 1922., 5-6.

96 „Osvrt na rad kazališta u ovoj sezoni”, Kazališni list (Osijek), 23. 12. 1922., 4.

97 HEĆIMOVIĆ, Repertoar hrvatskih kazališta, 488. 
1920. trajno nastanio u Beogradu i pridružio srpskom književnom krugu te je bio jedan od srpskih književnika koji su se 30-ih uz Crnjanskog angažirali „na očuvanju i održanju srpske nacije”, svrstavajući se „uz bok desničarskih, pa i ekstremistički nastrojenih organizacija". ${ }^{98}$ No za razliku od Crnjanskog, koji je ekstremno nacionalističko i militantno stajalište prihvatio tek 30 -ih godina, ono je kod Jankovića bilo prisutno već u ovoj drami. Njezina radnja odvija se $\mathrm{u}$ internacijskom logoru u Aradu, u koji su austrougarske vlasti tijekom rata internirale Srbe iz Monarhije. Internirani Srbi teško žive, uzaludno očekujući pomoć iz Srbije. Logorski stražar zaljubljen je u mladu Srpkinju, a ona se pretvara da prihvaća njegovu ljubav da bi pomogla svojim sunarodnjacima. Njoj u posjet s bojišta dolazi zaručnik, austrougarski časnik Vojin, Srbin, no on je slomljen čovjek i nije joj u stanju pomoći. Vrijeme je pravoslavnoga Uskrsa, noć je i logorski stražar pokušava silovati mladu Srpkinju. Nailazi Vojin i ubija nasilnika. Tim činom Vojin doživljava vlastito uskrsnuće i ponovo se osjeća živ, voljen i sposoban voljeti. ${ }^{99}$ Janković, inače sin pravoslavnoga svećenika, Kristovo uskrsnuće poistovjetio je s uskrsnućem svojega naroda u krvi, osveti.

U kazališnoj objavi kojom se pozivalo na predstavu Vojinov čin predstavljen je kao „pozitivan akt” jer je to ubojstvo omogućilo obnovu „vječnoga života”, kojega je dio i narod. U toj objavi uskrsnuću je oduzeto religiozno značenje te ga se predstavilo kao žarko oduševljenje trijumfom vječnoga života i narodom kao njegovim dijelom..$^{100}$ Osječki Hrvatski list, tadašnje glasilo federalističke Hrvatske zajednice, pisao je da je tom objavom upravitelj osječkoga kazališta Andrija Milčinović na predstavu kojom se navodno trebalo slaviti hrvatsko oslobođenje pozvao „osječke fašiste” te da se tom predstavom osječkom kazalištu ne briše samo „svaki biljeg hrvatstva već i umjetnosti i normalnih prilika". ${ }^{101}$

Iste je godine u studenom u Splitu izvedena „dramska epizoda iz srpsko-austrijskog rata” Hej Slaveni (Hej Sloveni) srpskoga književnika Riste Odavića. Ova jednočinka, čija se radnja odvija u Beogradu u vrijeme „prve okupacije Beograda u jesen 1914. godine u jednoj poznatoj beogradskoj kući”, praizvedena je u Skopju 1915. te je do druge polovine 20 -ih izvedena preko tri tisuće puta „u svim pozorištima gdje Srbi žive, čak i u Americi”. ${ }^{102}$ Drama je

98 MILIVOJEVIĆ-MAĐAREV, Fantastika u dramama Vladimira Velmar-Jankovića, 7, 17. Tijekom Drugoga svjetskog rata bio je pomoćnik Velibora Jonića, ministra prosvjete u vladi Milana Nedića, zbog čega je pred ulazak partizanske vojske u Beograd trajno emigrirao iz Srbije. Prema Oliveri Milosavljević, tijekom Drugoga svjetskog rata u Srbiji „najdalje je u sprovođenju nacionalsocijalističkih ideja otišlo Ministarstvo prosvete na čijem su se čelu tokom čitavog rata (1941-1944) nalazili Velibor Jonić i Vladimir Velmar-Janković”. MILOSAVLJEVIĆ, Potisnuta istina, 36.

99 „Theater, Kunst und Literatur”, Die Drau (Osijek), 10. 11. 1922., 3.

100 „Vrtlog”, Kazališni list (Osijek), 28. 10. 1922., 3-4.

101 „Theatralia”, Hrvatski list, 31. 10. 1922., 4.

102 Nakon rata Odavić je tu „dramsku epizodu” dopunio još dvjema jednočinkama: Pod križem (Pod krstom), čija se radnja odvija u okupiranoj Srbiji, te Poslije oslobođenja (Posle oslobođenja), čija se radnja odvija u poratnom Zagrebu, gdje se „odigrava ono što se događa neprestano od rata: zamera se, predbacuje i svakom prilikom ispolji nezadovoljstvo i protest 
u Splitu do svibnja 1923. izvedena ukupno tri puta, ${ }^{103}$ a nakon toga u svibnju 1926. i u Zagrebu, gdje je do travnja 1927. izvedena tri puta. ${ }^{104}$ Zagrebačka premijera bila je prigodno izvedena tijekom kongresa Udruženja rezervnih oficira i ratnika, organizacije ratnih veterana koja je njegujući srpsku kulturu pobjede uz veterane srpske formalno okupljala i veterane austrougarske vojske. ${ }^{105}$ Tom prilikom u Zagrebu je izvedena i ratna jednočinka $\mathrm{Na}$ Kosovo slovenskoga književnika Vitomila Feodora Jelenca, čija je radnja „uzeta iz bojeva srpske vojske za vrijeme rata, u kojima je učestvovao i autor kao dobrovoljac" ${ }^{106}$ Kako s hrvatske strane nije bilo prigodne ratne drame koja bi slavila srpsku kultu$r u$ pobjede, tom su prilikom pred ratnim veteranima izvedene „slike iz opere Nikola Šubić Zrinjski”."107

Odavićeva drama nije pobudila osobit interes hrvatske kritike; tek je $\mathrm{Hr}$ vatska pozornica, koju je uređivao hrvatski književnik i novinar jugoslavensko unitarističke orijentacije Stanko Tomašić, pišući isključivo o jednočinkama Odavića i Jelenca, navela da smo se tim predstavama „na časak prenijeli u devetstoosamnaestu godinu, kada se kod ovakvih komada cijelo kazalište orilo od pljeskanja ushićenih gledalaca, jer su srca bila zapaljena svetom vatrom patriotizma jugoslavenskog. [...] Ma da su to prosječni komadi u dramatskom i teatarskom pogledu, oni su ipak napisani patriotskim srcem proizveli snažan utisak na patriotske slušatelje". ${ }^{108}$

U Splitu je u kolovozu 1923. izvedena komedija Branislava Nušića Svjetski rat (Svetski rat) i više nije postavljana. ${ }^{109}$ Ista je drama u listopadu 1923.

protivu novih, poratnih prilika. Ipak jednim srećno nađenim i zanimljivim obratom uviđa se da to nije mržnja već samo bratska primedba”. „Premiera trilogije Duh naših dedova”, Comoedia (Beograd), 15. 1. 1927., 10-12.

103 HEĆIMOVIĆ, Repertoar hrvatskih kazališta, 383.

104 Isto, 132.

105 NJUMEN, Jugoslavija u senci rata, 77-86. Prema pisanju hrvatskoga federalističkog lista Hrvat, tih dana Zagreb je izgledao kao „garnizonski grad”. Ulice su bile pune časnika, „civila sa šajkačama na glavi”, te se tu nalazila i grupa „četnika u četničkoj odori” na čelu s njihovim vojvodom Kostom Pećancem. Izaslanstvo Udruženja rezervnih oficira u zagrebačkoj je katedrali položilo vijence na grob Petra Zrinskog i Frana Krste Frankopana, gdje je pričuvni časnik Radoslav Agatonović održao i prigodni govor. „Posveta zastave rezervnih oficira”, Hrvat (Zagreb), 25. 5. 1926., 2. Kult Zrinskog i Frankopana, pogubljenih 1671. u Bečkome Novom Mjestu, bio je izvorno pravaški i predstavljao je težnju Hrvata za neovisnošću, no uoči Prvoga svjetskog rata kao protuhabsburški kult prihvatili su ga i političari jugoslavenske orijentacije. GABELICA, „Pravaška mladež na hrvatskom Sveučilištu”, 1151-1155. Svoje viđenje proslave pričuvnih časnika u Zagrebu dao je KRLEŽA, Deset krvavih godina, 89-95.

106 „Vitomir Feodor Jelenc: Na Kosovo”, Hrvatska pozornica (Zagreb), 22. 5. 1926., 10-11. Zanimljivo je da je to bila jedina slovenska ratna drama izvedena u hrvatskim kazalištima u međuraću. O slovenskim ratnim dramama objavljenim u tom razdoblju vidi primjerice: GOLJEVŠČEK, Od A(brama) do Ž(upančiča), 128-129, 131-132, 222-223, 273-274, 456-457, 461-463, 866-867.

107 „Posveta zastave rezervnih oficira”, Hrvat, 25. 5. 1926., 2.

108 „Odavić: Hej Sloveni - F. Jelenc: Na Kosovo”, Hrvatska pozornica, 8. 6. 1926., 10-12.

109 HEĆIMOVIĆ, Repertoar hrvatskih kazališta, 385. 
izvedena u Osijeku, gdje je ponovljena još šest puta. ${ }^{110}$ Radnja komedije vrti se oko čovjeka „koji je rat proživio u podrumu”, a koji se četiri godine nakon rata ne miri s njegovim završetkom, nego po sobi s razvijenim vojnim kartama isprobadanim zastavicama „stvara najsmelije i najoriginalnije ratne planove". ${ }^{111}$ Hrvatska je kazališna kritika tu komediju prešutjela, a veću je pozornost izazvala još jedna drama iz srpskoga poslijeratnog društva. Riječ je o drami Pirovanje Mite Dimitrijevića, koja je premijerno izvedena u lipnju 1925. u Zagrebu, gdje je potom doživjela još šest izvedbi. ${ }^{112}$ U veljači 1926. izvedena je u Osijeku, gdje je ponovljena još jednom. ${ }^{113}$

Radnja drame odvija se nakon rata u Beogradu, gdje se "preživela pokolenja iza rata, a naročito novo, baca u jedan besan, izbezumljeni karneval”. Glavni lik je bivša ratna bolničarka koja je „prošla sve golgote Albanije i izgnanstva”. Ona se iz progonstva vraća kao već moralno posrnula žena, a u poslijeratnom Beogradu doživljava potpuni moralni pad. S dna ju diže bivši suprug, koji je kao nevino osuđen poslijeratne godine proveo u zatvoru, gdje je izoliran od društva uspio sačuvati stari, dobri, predratni i ratni moral. ${ }^{114}$ Hrvatska je kritika dramu beziznimno ocijenila lošom, s tim da su pojedini kritičari negativno ocjenjivali prije svega njezin umjetnički domašaj, gajeći određene simpatije za sadržaj, ${ }^{115}$ a drugi su napadali i umjetnički izražaj i sadržaj. ${ }^{116}$ Najoštriju kritiku njezina sadržaja iznio je neki, očito mladi, suradnik Hrvatskoga lista, koji je pisao da Dimitrijević u toj drami snagom „autoriteta starijeg pokoljenja” proklinje novu generaciju „koja više ne će da se skuči pod konvencionalne laži preratnog vremena, koja hoće da živi slobodnim životom jačeg pokoljenja”, i da Dimitrijević oštro osuđuje novu generaciju nesvjestan da su „forme, koje poprima današnji život svjetlije i snažnije od onoga života, što se provodio bez jazza i bez dansinga i bez 'grehova"'. ${ }^{117}$

Samo u splitskom kazalištu odigrana je punokrvna ratna drama Branislava Nušića Veliki tjedan (Velika nedelja), epska priča o povlačenju jedne srpske obitelji s vojskom kroz Albaniju do njezina povratka u domovinu na razruše-

\footnotetext{
110 Isto, 490.

111 „Nove Nušićeve komedije”, Kazališni list (Osijek), 17. 10. 1923., 5.

112 HEĆIMOVIĆ, Repertoar hrvatskih kazališta, 130.

113 Isto, 493.

114 „Pirovanje”, Kazališni list (Osijek), 11. 2. 1926., 69-70.

115 „Pirovanje”, Jugoslavenska njiva, god. 9 (1925), knj. 2, br. 1, 30-31; Milutin NEHAJEV, „Pirovanje”, Jutarnji list, 16. 6. 1925., 5; Stjepan PARMAČEVIĆ, „Pirovanje”, Riječ, 15. 6. 1925., 3.

116 Eustahije JURKAS, „Pirovanje”, Hrvat, 18. 6. 1925., 2; Milan BEGOVIĆ, „Hrvatsko kazalište”, Večer, 16. 6. 1925., 3; Ivan NEVISTIĆ, „Hrvatsko kazalište”, Vijenac (Zagreb), god. 3 (1925), knj. 5, br. 1-2, 35-36.

117 Bk, „Pirovanje”, Hrvatski list, 3. 3. 1926., 2. Suprotno tomu, srpski književni kritičar Milan Bogdanović mislio je da ta drama nije postigla tendenciju kritike „prljavog posleratnog života” jer se u njoj osjeća „naklonost piščeva da stvari primi onakve kakve su, da im nađe tumačenje ako ne i opravdanje”. „Greh je tako malo podvučen, da čovek ostaje pod utiskom da je g. Dimitrijević nadahnut jednom hrišćanskom dobrotom za grešnike i krivce." Milan BOGDANOVIĆ, „Pozorišni pregled”, Srpski književni glasnik, 1926., knj. 19, br. 3, 218-220.
} 
no ognjište, koja je sadržavala punu sliku srpske kulture pobjede: „Muku, Raspeće, Vaskrs! Borbe, prijelaz preko Albanije, i povratak u slobodnu otadžbinu." ${ }^{118}$ Ova drama, u kojoj su isticana „stara preimućstva naše rase i morala”, imala je svoj „vaspitni značaj prvenstveno za mlađe generacije, koje pokušavaju da zaborave ono šta smo im pričali”, te je napisana „radi naše budućnosti, koja treba da postane sasvim svesna tih muka”. Jer „trebalo je pet stotina godina pevanja i plastičnog prikazivanja tragedije na Kosovu, da taj nauk donese koristi”, pa je trebalo i „odmah početi s prikazivanjem skorog napora kako bi svaki moment potsećanja bio iskorišten”. 119

Splitska premijera drame bila je u studenom 1925. te je do prosinca iste godine izvedena još tri puta. ${ }^{120}$ Znakovito je da se splitska premijera dogodila čak četiri godine prije beogradske, ${ }^{121}$ što svjedoči o jugoslavensko-unitarističkom ideološkom čistunstvu splitske kazališne uprave. ${ }^{122} \mathrm{~S}$ tih je ideoloških stajališta tu dramu popratio suradnik splitskoga jugoslavensko-unitarističkog lista Novo doba ${ }^{123}$ Ivo Lahman, koji je uz blagu kritiku umjetničke strane djela isticao da je ono „teški i krvavi pasion generacije” koja je „kao Hrist na Maslinskoj gori, na prelomu dviju epoha predosjećala sa zebnjom ulogu koja joj je bila namijenjena” te koja se pokazala dostojnom svojega poslanja izborivši pobjedu ,jedne davne naše rasne ideologije, jednog potmulog ali nemirnog atavizma, koji je na kraju svega, morao da donese triumf jedinstva". ${ }^{124}$ Kritičniji prema drami pokazao se predratni član jugoslavenske nacionalističke omladine u Dalmaciji te srpski ratni dobrovoljac Milostislav Bartulica, koji se $u$ to vrijeme počeo približavati Hrvatskoj seljačkoj stranci. ${ }^{125}$ Iako je i on u osvrtu naveo da drama obrađuje „srpsku Golgotu” u Albaniji, što je nemjerljiva tragedija jednoga naroda, pisao je i da je Nušić u obradi te teme pribjegao patetičnim efektima („neprestano jaukanje i sav onaj beskonačan plač”), zbog čega je dramu ocijenio umjetnički manjkavim djelom. ${ }^{126}$

Pukovnik Jelić Milivoja Predića posljednja je srpska drama ratne tematike izvedena u nekom od hrvatskih kazališta. U njoj srpski heroj i ratni invalid, ne snalazeći se u poslijeratnom društvu, doživljava društveni pad. ${ }^{127}$ Drama je

\footnotetext{
118 „Narodno pozorište u Sarajevu”, Comoedia, 28. 9. 1925., 6.

119 Vidi: „Reditelj Velike nedelje g. Ginić smatra da komad mogu da gledaju samo oni ljudi koji imaju jake nerve".

${ }^{120}$ HEĆIMOVIĆ, Repertoar hrvatskih kazališta, 388.

${ }^{121}$ Beogradska premijera izvedena je 26. listopada 1929., „na dan oslobođenja Skoplja”. Vidi: „Pred sutrašnju premijeru”.

${ }^{122} \mathrm{O}$ „orjunaškoj” orijentaciji splitske kazališne uprave (Niko Bartulović, Mirko Korolija) vidi primjerice: KOŠUTIĆ-BROZOVIĆ, „Hrvatsko dramsko prevoditeljstvo”, 272, 286.

${ }^{123}$ KUIĆ, „Novo doba”, 121-124.

124 Ivo LAHMAN, „Branislav Gj. Nušić: Velika nedjelja”, Novo doba, 10. 11. 1925., 4.

${ }^{125}$ KOLAR, „Lika u vrijeme dominacije Seljačko-demokratske koalicije”, 516.

126 Milostislav BARTULICA, „Mali feuilleton”, Obzor, 10. 11. 1925., 3.

${ }^{127} \mathrm{U}$ dijelu srpske kazališne kritike ta je drama doživljena kao napad na dostojanstvo srpske žrtve u Prvom svjetskom ratu. Tako je Milan Bogdanović u njoj prepoznao dva problema: problem ratnoga heroja koji se ne snalazi u poslijeratnom društvu i problem dužnosti supruge prema „heroju, stradalniku u jednoj borbi koja je vezana za visoke nacionalne ideale”.
} 
izvedena samo u Splitu, i to 29. listopada 1926., na dan prekida državnopravnih veza Hrvatske s Ugarskom i Austrijom, te je ponovljena samo u studenom iste godine. ${ }^{128}$ Pišući o njezinoj izvedbi, Ivo Lahman primijetio je nerazmjer između pozornice i gledališta: „Na pozornici: snažna, tragična apoteoza žrtve pukovnika Jelića, koji je u ratu izgubio svoju tjelesnu snagu, i kad želi da je nadoknadi sa duševnom, poratno društvo mu je otima i uništava. A u gledalištu: praznina! Skoro potpuna praznina!" Lamentirajući o nezahvalnosti poslijeratne generacije, i one u drami i one u splitskom gledalištu, koja je pohrlila na kinopredstave, „a u pakao u kući ratnog heroja i žrtve, u Sibiriju u duši jednog personificiranog predstavnika onog viteštva koje je napisalo istoriju ovog naroda nije htio gotovo nitko da zaviri”, Lahman je dvojio hoće li se ikad više naći itko tko će se poput pukovnika Jelića žrtvovati za više ciljeve. ${ }^{129}$

Nakon 1926. ni u jednom od hrvatskih kazališta nije izvedena nijedna srpska ratna drama, pa tako ni novosadsko-osječko kazalište na repertoaru nije imalo nijednu takvu dramu bilo iz prethodnoga razdoblja, kao što su primjerice Poljska bolnica Vladimira Stanimirovića (1920.), Tuđinče Branislava Nušića (1921.) ili U zatišju Uroša Dojčinovića (1925.), bilo iz kasnijega razdoblja, kao što su primjerice Tamo daleko Milice Jakovljević Mirjam (1930.) ili Srpska trilogija Stevana Jakovljevića (1938.). Na temelju ovdje iznesenog pregleda možemo zaključiti da je u hrvatskim kazalištima u međuratnom razdoblju izvedeno šest srpskih ratnih drama, koje su ukupno bile izvedene 32 puta. U Zagrebu su dvije takve drame izvedene deset puta, u Osijeku tri drame dvanaest puta, a u Splitu četiri drame deset puta. Znakovito je da su dvije od njih (Vrtlog i Pukovnik Jelić) premijerno izvedene 29. listopada, na dan hrvatskoga prekida državnopravnih veza s Austrijom i Ugarskom, čime se htjelo demonstrirati povezanost hrvatskoga oslobođenja sa srpskom ratnom pobjedom. Prigodničarski karakter imala je i zagrebačka premijera Odavićeve drame, kojom se htjela uveličati proslava rezervnih časnika.

\footnotetext{
Bogdanović je smatrao da je autor na nezadovoljavajući način pristupio rješenju obaju problema. Predbacio mu je da je pukovnika Jelića predstavio kao častohlepnoga i plitkoga čovjeka, a ne idealista, pa se „na mahove čini čoveku da on žali svoju žrtvu”. Prema Bogdanoviću, autor je posebno loše riješio pitanje „prava mlade žene da od života zahtijeva više zadovoljstva nego što može imati uz obogaljenog muža” jer Jelićeva žena vara svojega muža, „koji je paćenik i prema kome se mora imati jedno poštovanje”, i to „sa prvim nikakvim koji je naišao, [tako] da u oceni njena karaktera ne može biti sumnje”. Milan BOGDANOVIĆ, „Pukovnik Jelić od Milivoja Predića”, Srpski književni glasnik, 1925., knj. 16, br. 6, 442-444.

${ }^{128}$ HEĆIMOVIĆ, Repertoar hrvatskih kazališta, 389.

129 Ivo LAHMAN, „Milivoj Predić: Pukovnik Jelić”, Novo doba, 31. 10. 1926., 4.
} 


\section{Zaključak}

U hrvatskim je kazalištima u međuraću izvedeno petnaest inozemnih i srpskih ratnih drama. Najviše je izvedeno srpskih, njih šest, u kojima se njegovala srpska kultura pobjede u opreci kojoj se javljala i kritika srpskoga poslijeratnog društva. Slijedile su britanske (američke) i francuske ratne drame, njih pet, koje je karakterizirao naglašeni pacifizam. Najmanje je bilo izvedeno čehoslovačkih ratnih drama, njih četiri, koje su uz protuaustrijsku sadržavale i notu češkoga nacionalizma. Sasvim obratno stanje vidljivo je na temelju broja njihovih izvedbi. Najizvođenije su čehoslovačke ratne drame (oko 130 puta), slijedile su britanske (američke) i francuske (oko 60 puta), a najmanje su bile izvođene srpske ratne drame (32 puta). Kronološki, sve su srpske ratne drame izvedene u prvim poratnim godinama, do 1926., a sve inozemne od 1928. do zaključno 1939. godine.

Ako hrvatska kazališta u međuratnom razdoblju shvatimo kao mjesta sjećanja koja su svojom kazališnom politikom stvarala sadržaje hrvatske kulture sjećanja na Prvi svjetski rat, onda bi se na temelju iznesenih podataka moglo zaključiti da su sastavni dijelovi hrvatske kulture sjećanja na taj rat bili motivi srpske ratne pobjede, pacifizma i kritike austrijskoga militarizma s primjesom češkoga nacionalizma. Ukupno gledajući, motiv srpske ratne pobjede bio je najsnažnije forsiran, no sudeći po broju izvedbi, hrvatska je publika taj motiv i najmanje prihvaćala. $S$ druge strane taj je motiv u prvim poratnim godinama, kada je postojala i tendencija da ga se izravno poveže s hrvatskim oslobođenjem, jedini i bio prisutan. Najmanje je bio forsiran motiv kritike austrijskoga militarizma s primjesom češkoga nacionalizma, no taj je motiv hrvatska publika najspremnije prihvaćala.

Ako na temelju dosadašnjega istraživanja hrvatske književne baštine znamo da je „institucionalno podupirano” i dominantno hrvatsko sjećanje na Prvi svjetski rat predočeno u Krležinu ratnom ciklusu, gdje se kao simbol hrvatskoga sudjelovanja u tom ratu javlja kolektivni (anti)junak: neratoborni, nepismeni i prisilno mobilizirani zagorski domobran u dalekoj i blatnoj Galiciji koji se protiv svoje volje bori za Austro-Ugarsku Monarhiju, onda možemo zaključiti da se ovdje navedena prihvaćenost čehoslovačkih ratnih drama i motiva sadržanog u njima uvelike podudarala s dominantnim hrvatskim sjećanjem na rat. Čehoslovačke su drame bile „institucionalno podupirane" u smislu da su postavljane na repertoar hrvatskih kazališta, a neke druge nisu, no po tome što je hrvatska javnost (publika) između triju navedenih grupa nehrvatskih ratnih drama najviše prihvaćala upravo njih možemo zaključiti da su od ponuđenih ratnih drama one čehoslovačke u postojećim okolnostima najviše odgovarale i spontanom hrvatskom sjećanju na Prvi svjetski rat. 


\section{Tisak}

Comoedia (Beograd), 1925, 1927.

Danas (Beograd), 1934.

Die Drau (Osijek), 1922.

Hrvat (Zagreb), 1925-1926.

Hrvatska pozornica (Zagreb), 1926.

Hrvatska revija (Zagreb), 1929-1930, 1934, 1936.

Hrvatska smotra (Zagreb), 1939.

Hrvatska straža (Zagreb), 1930, 1932.

Hrvatski list (Osijek), 1922, 1926, 1936.

Jadranski dnevnik (Split), 1935.

Jugoslavenska njiva (Zagreb), 1919, 1925.

Jutarnji list (Zagreb), 1925, 1931-1932, 1934.

Kazališni list (Osijek), 1922-1923, 1926.

Kazališni list (Split), 1931.

Kazališni list (Zagreb), 1933.

Književnik (Zagreb), 1930, 1934.

Komedija (Zagreb), 1936, 1939.

Luč (Zagreb), 1932/1933.

Narodne novine (Zagreb), 1936.

Nedjelja (Zagreb), 1930.

Novo doba (Split), 1923, 1925-1926, 1931, 1935.

Novosti (Zagreb), 1930, 1932, 1934.

Obzor (Zagreb), 1922, 1925, 1930-1931, 1936.

Omladina (Zagreb), 1934.

Riječ (Zagreb), 1925, 1931.

Savremeni pogledi (Slavonski Brod), 1936.

Srpski književni glasnik (Beograd), 1922, 1925-1926, 1931, 1937.

Večer (Zagreb), 1925, 1934, 1936.

Vijenac (Zagreb), 1925.

\section{Literatura}

ASSMANN, Jan. „Kultura sjećanja”. U: Kultura pamćenja i historija, prir. Maja Brkljačić i Sandra Prlenda. Zagreb: Golden marketing-Tehnička knjiga, 2006, 45-78.

BATUŠIĆ, Ivana. „Francuski umjetnici na zagrebačkoj pozornici od 1891. do 1940. godine”. Rad JAZU 257 (1953): 5-88. 
BATUŠIĆ, Slavko. Hrvatska pozornica. Studije i uspomene. Zagreb: Mladost, 1978.

BATUŠIĆ, Slavko. „Vlastitim snagama (1860.-1941.)”. U: Enciklopedija Hrvatskoga narodnog kazališta u Zagrebu, ur. Pavao Cindrić. Zagreb: Naprijed, 1969, 128-133.

BOGNER-ŠABAN, Antonija. „Hrvatsko narodno kazalište u Osijeku u povijesnom i kulturnom središtu". U: Hrvatsko narodno kazalište u Osijeku: 1907.-2007., ur. Antonija Bogner-Šaban. Osijek: Hrvatsko narodno kazalište, 2007, 9-23.

CAR, Milka. Odrazi i sjene. Njemački dramski repertoar u Hrvatskom narodnom kazalištu u Zagrebu do 1939. godine. Zagreb: Leykam international, 2011.

ĐORĐEVIĆ, Bojan. „Teatar u Splitu u doba Desničine mladosti: politika i kultura”. U: Split i Vladan Desnica 1918.-1945. Zbornik radova s Desničinih susreta 2015., ur. Drago Roksandić i Ivana Cvijović Javorina. Zagreb: Filozofski fakultet, 2016, 195-210.

FLOD, Ivan. „Osječko kazalište od 1907. do 1941. Kazališna misao u Osijeku”. U: Spomen-knjiga o pedesetoj godišnjici Narodnog kazališta u Osijeku: 1907.-1957., prir. Dubravko Jelčić. Osijek: Narodno kazalište, 1957, 94-113.

GABELICA, Mislav. „Dramski repertoar Kraljevskoga zemaljskoga hrvatskog kazališta tijekom Prvoga svjetskog rata". Časopis za suvremenu povijest 47 (2015), br. 1: 103-138.

GABELICA, Mislav. „Pravaška mladež na hrvatskom Sveučilištu uoči Prvoga svjetskog rata”. Društvena istraživanja 20 (2011), br. 4 (114): 1139-1161.

GABELICA, Mislav; MATKOVIĆ, Stjepan. Petoprosinačka pobuna u Zagrebu 1918. Zagreb: Naklada Pavičić, 2018.

GADBERRY, Glen W. „Introduction: The Year of Power-1933”. U: Theatre in the Third Reich, the Prewar Years. Essays on Theatre in Nazi Germany, ur. Glen W. Gadberry. Westport-London: Greenwood Press, 1995, 1-17.

GOLJEVŠČEK, Alenka. Od A(brama) do Ž(upančiča). Vsebine 765 dram slovenskih avtorjev. Ljubljana: Slovenski gledališki muzej, 2011.

HAMERŠAK, Filip. „Nacrt za pristup kulturnoj povijesti Prvoga svjetskog rata iz hrvatske perspektive". Dani Hvarskoga kazališta. Prvi svjetski rat u kulturnom pamćenju 41 (2015): 5-73.

HAMERŠAK, Filip. „Od romana do izvedbe - prilog poznavanju Švejkove teatarske anabaze". Kolo (2008), br. 3-4: 126-149.

HAMERŠAK, Filip. Tamna strana Marsa. Hrvatska autobiografija i Prvi svjetski rat. Zagreb: Naklada Ljevak, 2013.

HEĆIMOVIĆ, Branko. „Hrvatska dramska književnost između dva rata”. Rad JAZU 353 (1968): 111-319.

HEĆIMOVIĆ, Branko, ur. Repertoar hrvatskih kazališta: 1840-1860-1980., knj. 1. Zagreb: Globus, 1990. 
JAREB, Mario. Ustaško-domobranski pokret od nastanka do travnja 1941. godine. Zagreb: Školska knjiga, 2006.

JELČIĆ, Dubravko, prir. Spomen-knjiga o pedesetoj godišnjici Narodnog kazališta u Osijeku 1907-1957. Osijek: Narodno kazalište, 1957.

JONJIĆ, Tomislav. Hrvatska vanjska politika 1939.-1942. Zagreb: Libar, 2000.

JONJIĆ, Tomislav; MATKOVIĆ, Stjepan. Iz korespondencije dr. Mile Budaka (1907. - 1944.). Zagreb: Hrvatski državni arhiv, 2012.

KOLAR, Mira. „Lika u vrijeme dominacije Seljačko-demokratske koalicije u skupštini Primorsko-krajiške oblasti 1927. i 1928. godine”. U: Identitet Like: korijeni i razvitak, ur. Željko Holjevac. Gospić: Institut društvenih znanosti Ivo Pilar, 2007, 503-547.

KOŠUTIĆ-BROZOVIĆ, Nevenka. „Francuske književne pobude u časopisima hrvatske moderne". Rad JAZU 355 (1969): 403-665.

KOŠUTIĆ-BROZOVIĆ, Nevenka. „Hrvatsko dramsko prevoditeljstvo u međuratnom razdoblju”. Dani Hvarskoga kazališta 9 (1982): 272-337.

KRLEŽA, Miroslav. Deset krvavih godina i drugi politički eseji. Zagreb: Zora, 1971.

KUIĆ, Ivanka. „Novo doba - najvažniji splitski i dalmatinski list između dva rata”. Kulturna baština (2013), br. 39: 113-138.

LASIĆ, Stanko. Mladi Krleža i njegovi kritičari (1914-1924). Zagreb: Globus, 1987.

MANOJLOVIĆ PINTAR, Olga. Arheologija sećanja. Spomenici i identiteti u Srbiji 1918-1989. Beograd: Čigoja štampa. Udruženje za društvenu istoriju, 2014.

MARIJANOVIĆ, Stanislav. „Hudožestvenici u Osijeku”. U: Krležini dani u Osijeku 1997. Hrvatska dramska književnost $i$ kazalište u europskom kontekstu, knj. 1. Zagreb; Osijek, 1999, 334-341.

MATKOVIĆ, Stjepan. „Ratni zločini nad Hrvatima u Odesi 1916. (I)” Politički zatvorenik 13 (2003), br. 140: 34-38.

MATKOVIĆ, Stjepan. „Ratni zločini nad Hrvatima u Odesi 1916. (II)” Politički zatvorenik 13 (2003), br. 141: 36-42.

MATKOVIĆ, Stjepan. „Ratni zločini nad Hrvatima u Odesi 1916. (III)” Politički zatvorenik 13 (2003), br. 142: 35-39.

McCREADY, Susan. „French Theater and the Memory of the Great War”. Studies in 20th \& 21st Century Literature 41 (2017), br. 2: 1-13.

MILOSAVLJEVIĆ, Olivera. Potisnuta istina. Kolaboracija u Srbiji 19411944. Beograd: Helsinški odbor u Srbiji, 2006.

MOMBAUER, Annika. Uzroci Prvog svjetskog rata: kontroverze i konsenzus. Zagreb: Naklada Ljevak, 2014.

MUCIĆ, Dragan. Prvih četrdeset godina: Hrvatsko narodno kazalište u Osijeku 1907.-1941. Osijek: Matica hrvatska, Ogranak Osijek; Filozofski fakultet u Osijeku, 2010. 
NOVAK, Božidar. Hrvatsko novinarstvo u 20. stoljeću. Zagreb: Golden marketing-Tehnička knjiga, 2005.

NJUMEN, Džon Pol. Jugoslavija u senci rata. Ratni veterani $i$ stvaranje nove države 1903-1945. Beograd: Službeni glasnik, 2017.

PERIČIĆ, Helena. Posrednici engleske književnosti u hrvatskoj književnoj kritici u razdoblju od 1914. do 1940. godine. Zagreb: Hrvatsko filološko društvo, 2003.

PERUŠKO, Ivana. „Rat i mir 20. stoljeća”. Vijenac (Zagreb) (2013), br. 501: $13-14$

PETRANOVIĆ, Marina. „Dva slavonska Povratka (Srđan Tucić i Zlata Kolarić Kišur)”. Šokačka rič 3 (2006): 115-143.

POPOVIĆ, Radovan. Život Miloša Crnjanskog. Beograd: Prosveta, 1980.

RADA, Ivan; VRANIČEK, Vratislav; ČORNEJ, Petr; ČORNEJEVÁ, Ivana; BÉLINA, Pavel; RAK, Jiř́i HALADA, Jaroslav; MORAVCOVÁ, Dagmar; TOMEŠ, Josef; HRBEK, Jaroslav; MAREŠ, Petr; GRULICH, Tomáš; ROČEK, A. Petr. Povijest Češke. Od seobe Slavena do suvremenog doba. Zagreb: Sandorf, 2014.

RENOUVIN, Pierre. Europska kriza i Prvi svjetski rat. Zagreb: Golden marketing-Tehnička knjiga, 2008.

SACHS, Leon; McCREADY, Susan. „Stages of Battle: Theater and War in the Plays of Bernhardt, Raynal and Anouilh”. The French Review 87 (2014), br. 4: 41-55.

SENKER, Boris. Hrestomatija novije hrvatske drame (1895-1940). Zagreb: Disput, 2000.

VAGAPOVA, Natalija. „Hrvatsko kazalište 20. stoljeća i umjetnost Moskovskog hudožestvenog teatra”. U: Krležini dani u Osijeku 1997. Zagreb: Zavod za povijest hrvatske književnosti kazališta i glazbe HAZU, Odsjek za povijest hrvatskog kazališta; Osijek: Hrvatsko narodno kazalište: Pedagoški fakultet, 1999., 334-341.

VAGAPOVA, Natalija. „Skupine glumaca Moskovskog hudožestvenog teatra u Srednjoj Europi (1920-1930)”. Književna smotra 33 (2001), br. 119 (1): $29-42$.

\section{Internetski sadržaj}

ATANASIJEVIĆ, Konstantin. „Grob neznanog junaka od Pol Renala”. Narodna biblioteka Srbije. Pristup ostvaren 20. 8. 2020. https://www.digitalna.nb.rs/sf/NBS/Tematske_kolekcije/Pozorisnie_kritike_Narodnog_pozorista_1931-1944

KRNIĆ, Dušan. „Jakovljevićeva Srpska trilogija na pozornici”. Narodna biblioteka Srbije. Pristup ostvaren 20. 8. 2020. https:/www.digitalna. nb.rs/sf/NBS/Tematske_kolekcije/Pozorisnie_kritike_Narodnog_pozorista_1931-1944 
MILIVOJEVIĆ-MAĐAREV, Marina. Fantastika u dramama Vladimira Velmar-Jankovića. Pristup ostvaren 1. 9. 2020. https://www.academia. edu/32456150/Fantastika_u_dramama_Vladimira_Velmar_Jankovi\%C4\%87a_U_prilogu_drame_Vladimira_Velmar_Jankovi\%C4\%87a_Robovi_Sre\%C4\%87a_A_D_i_Dr\%C5\%BEavni_neprijatelj_br_3_.

„Pred sutrašnju premijeru”. Narodna biblioteka Srbije. Pristup ostvaren 20. 8. 2020. www.digitalna.nb.rs/sf/NBS/Tematske_kolekcije/Pozorisnie_kritike_Narodnog_pozorista_1921-1930

„Reditelj Velike nedelje g. Ginić smatra da komad mogu da gledaju samo oni ljudi koji imaju jake nerve". Narodna biblioteka Srbije. Pristup ostvaren 20. 8. 2020. www.digitalna.nb.rs/sf/NBS/Tematske_kolekcije/Pozorisnie_kritike_Narodnog_pozorista_1921-1930

„Za zasluge. Drama u tri čina od Somerset Mona”. Narodna biblioteka Srbije. Pristup ostvaren 20. 8. 2020. https://www.digitalna.nb.rs/sf/NBS/Tematske_kolekcije/Pozorisnie_kritike_Narodnog_pozorista_1931-1944 


\section{World War I in the Culture of Memory: Foreign and Serbian War Dramas on the Repertoires of Croatian Theatres 1919-1941}

In this paper, the author approaches Croatian theatres as places of memory, and the foreign and Serbian war dramas performed in them as the contents of the Croatian culture of memory regarding World War I. Drawing upon the extant research on Croatian memory of World War I, based on examining the Croatian literary heritage, according to which the predominant Croatian memory was presented in Miroslav Krleža's war cycle, the author has attempted to answer the question, how did these non-Croatian war dramas on the repertoire of Croatian theatres correspond to the stated Croatian relationship towards World War I according to their contents, frequency of performance, and public reactions to them (as seen through theatre reviews)? In this sense, the author has identified three groups of non-Croatian war dramas: British (American) and French, which were characterised by prominent pacifism; Czechoslovak, which were anti-Austrian and contained a note of Czech nationalism; and Serbian, which nurtured the Serbian victory culture, but also criticised post-war Serbian society. Analysing these dramas, the author has concluded that Serbian war dramas enjoyed the strongest 'institutional support', but were also the least popular with the Croatian public. Czechoslovak war dramas received the least 'institutional support', but were the most popular among the Croatian public. Based on this analysis, the author has concluded that the Czechoslovak dramas had the most in common with the predominant Croatian memory of World War I in the interwar period; even though they did not receive much 'institutional support', they were the closest to the Croatian memory of the war in the given circumstances.

Key words: World War I; theatre; war drama; Croatian public 